NBER WORKING PAPER SERIES

TECHNOLOGY AND RESILIENCE

\author{
Diego A. Comin \\ Marcio Cruz \\ Xavier Cirera \\ Kyung Min Lee \\ Jesica Torres \\ Working Paper 29644 \\ http://www.nber.org/papers/w29644
}

\author{
NATIONAL BUREAU OF ECONOMIC RESEARCH \\ 1050 Massachusetts Avenue \\ Cambridge, MA 02138 \\ January 2022
}

We have greatly benefited from discussions with Miriam Gensowski, Denis Medvedev, Trang Thu Tran, Stephen Yeo, and Mark Dutz. We also thank our colleagues at the World Bank, the ANSD (Senegal), the GSO (Vietnam), and the Industry Association of Ceará (Brazil) who supported the collection of the survey data. All errors are our own. The views expressed in this article are solely those of the authors and do not necessarily reflect the views of the World Bank, its Executive Directors, the countries they represent, or the National Bureau of Economic Research.

NBER working papers are circulated for discussion and comment purposes. They have not been peer-reviewed or been subject to the review by the NBER Board of Directors that accompanies official NBER publications.

(C) 2022 by Diego A. Comin, Marcio Cruz, Xavier Cirera, Kyung Min Lee, and Jesica Torres. All rights reserved. Short sections of text, not to exceed two paragraphs, may be quoted without explicit permission provided that full credit, including () notice, is given to the source. 
Technology and Resilience

Diego A. Comin, Marcio Cruz, Xavier Cirera, Kyung Min Lee, and Jesica Torres

NBER Working Paper No. 29644

January 2022

JEL No. I15,O12,O33

\section{$\underline{\text { ABSTRACT }}$}

This paper estimates the impact of technology sophistication pre-COVID-19 on the performance of firms during the early stages of the pandemic. We exploit a unique data covering firms from Brazil, Senegal, and Vietnam using a treatment effect mediation framework to decompose the results into a direct and an indirect effect. Increasing pre-pandemic technology sophistication by one standard deviation is associated with 3.8pp higher sales. Both effects are positive, but the direct effect is about 5 times larger than the indirect effect. The total effect on sales is markedly nonlinear with significantly smaller estimates of the reduction in sales for firms with more sophisticated pre-pandemic technology. Our results are robust to different measures of digital responses and matching estimators.

Diego A. Comin

Dartmouth College

Economics Department

6106 Rockefeller Hall, Room 327

Hanover, NH 03755

and CEPR

and also NBER

diego.comin@dartmouth.edu

Marcio Cruz

The World Bank

1818 H Street, NW

Washington, DC 20433

marciocruz@worldbank.org

Xavier Cirera

The World Bank

1818 H ST NW

Washington, DC 20433

xcirera@worldbank.org
Kyung Min Lee

The World Bank

1818 H St., NW

Washington, DC 20433

klee12@worldbank.org

Jesica Torres

The World Bank

1850 I Street NW

CP 66269

Washington, DC 20006

jesicatorrescoronado@gmail.com 


\title{
Technology and Resilience
}

\author{
Xavier Cirera, ${ }^{1}$ Diego Comin, ${ }^{2}$ Marcio Cruz ${ }^{1 *}$ Kyung Min Lee $^{1}$ Jesica Torres $^{1}$ \\ ${ }^{1}$ The World Bank, \\ ${ }^{2}$ Dartmouth College
}

*To whom correspondence should be addressed; E-mail: marciocruz@worldbank.org.

This paper estimates the impact of technology sophistication pre-COVID-19 on the performance of firms during the early stages of the pandemic. We exploit a unique data covering firms from Brazil, Senegal, and Vietnam using a treatment effect mediation framework to decompose the results into a direct and an indirect effect. Increasing pre-pandemic technology sophistication by one standard deviation is associated with 3.8pp higher sales. Both effects are positive, but the direct effect is about 5 times larger than the indirect effect. The total effect on sales is markedly nonlinear with significantly smaller estimates of the reduction in sales for firms with more sophisticated pre-pandemic technology. Our results are robust to different measures of digital responses and matching estimators.

\section{Introduction}

The COVID-19 pandemic and the measures adopted to mitigate the spread of the virus changed dramatically the conditions in which businesses operated. Firms experienced simultaneously supply and demand shocks. Businesses faced closure of operations, bottlenecks on inputs, and reduced mobility for their workers worldwide. Consumers' mobility was also restricted and demand for most firms was negatively affected through different channels, including uncertainty and household income losses. The severity of the effect of these shocks on businesses has been well-documented 
across countries (1-7).

Despite the global nature of the shock, the impact of the pandemic has varied significantly across firms. While some economic activities, such as tourism, have been hit hard by the restrictive mobility measures, there is a large variation in performance within sectors and regions, which suggests that some firms have been more resilient in the face of a similar exogenous shock. Understanding the factors driving firms' resilience in the pandemic is essential in designing more effective policies, and potentially reducing the economic costs of measures to mitigate the health costs of any present and future pandemic. This goal is particularly relevant for developing countries where public resources are more limited and businesses are less likely to receive direct government support (8).

There are many factors that might explain cross-firm differences in performance during the pandemic. One that has received much attention in the literature is the use of digital technologies, such as online and integrated digital management systems, supply chain management systems, or online sales. Recent evidence on the increased use of digital technologies in response to COVID$19(1,9,10)$ supports the notion that the pandemic increased the returns to digitalization. Yet we know little about why certain firms implemented digital technologies while others did not. More importantly, research has so far not examined the extent to which firms' resilience to the COVID19 shock is due to their adoption of digital technologies, as opposed to the direct effect on firm performance of pre-COVID firm characteristics (which also influence digitization).

The goal of this paper is to understand one of the sources of firm resilience during the COVID19 pandemic. The specific question we explore here is how pre-pandemic technology sophistication - denoted as technology readiness - affected firm performance during the early stage of the pandemic. Our analysis relies on a treatment effect mediation framework (11-14) that has been used to disentangle the channels by which stimuli affect behavior. In our context, exogenous variation in pre-pandemic technology sophistication may affect firm resilience both directly, by facilitating operations and interactions with workers, customers, and suppliers in a context of an unexpected shock that abruptly reduce mobility and increase transaction costs among these actors, 
and indirectly via its effect on the adoption of additional digital technologies during the pandemic. Two conditions are necessary for the adoption of digital technologies to be a mediator in the relationship between technology readiness and firm resilience. First, that pre-pandemic technology sophistication is associated with an increasing use of digital technologies during the pandemic. Second, that variation in the adoption of digital technologies during the pandemic is significantly associated with firm resilience.

To estimate this statistical model, we use unique firm-level datasets that include firms in Brazil, Senegal, and Vietnam. The data provide granular pre-pandemic measures of the sophistication of the technologies used by firms in conducting seven key business functions - business administration, production/service planning, supply chain management, marketing, sales, payments and quality control - combined with information on whether firms started or increased the use of digital technology during the early stages of the pandemic; as well as their respective sales performance. Our analysis controls for several observable characteristics of the firm (e.g., age, size, exporting status, foreign ownership), including manager's human capital (e.g., level of education and work experience) and managerial practices (e.g., incentives to workers and performance indicators) that could simultaneously influence digital adoption and performance of the firm. In addition, we use high-frequency measures of urban mobility and disaggregated sectoral information to control for the heterogeneity in the stringency of the measures adopted and the severity of the shock.

Our findings show that technology readiness helped firms to offset some of the initial negative impact of the pandemic on sales not only directly, but also indirectly by facilitating the use of additional digital tools. Increasing pre-pandemic technology sophistication by one standard deviation is associated with 3.8 percentage points (pp) higher monthly sales, relative to the same period in 2019. We decompose this estimate into the direct $(3.1 \mathrm{pp})$ and indirect $(0.7 \mathrm{pp})$ effects. The indirect effect results from the fact that increasing pre-pandemic technology readiness by one standard deviation is associated with an increase in the likelihood that firms increase the use of digital technologies during the pandemic by $10 \mathrm{pp}$. Furthermore, the marginal likelihood of increasing digitization is higher for the firms with higher pre-pandemic technology sophistication. Both the 
direct and indirect effects on sales are larger among firms in the top quintiles of technology readiness. Our findings are robust to using different measures of digital response as a mediator, as well as to using propensity score or nearest-neighbor matching estimators for the indirect effect.

Previous studies have investigated the effects of work-from-home feasibility based on occupation of workers (15), and technology diversification based on the scope of patent applications (16) on firm performance during the COVID-19 pandemic or other natural disasters. Our analysis contributes to this literature on the effects of technology on firm resilience in three ways. First, we provide evidence on the positive relationship between pre-pandemic technology and firm resilience by using direct, granular measures of the sophistication of technologies, instead of proxies based on occupations or patents. Second, we decompose the effect of technology readiness on firm performance into a direct effect and an indirect effect through the adoption of digital technologies that allow firms to better cope with the shock. Third, we assess the possibility of a non-linear relationship between pre-pandemic technology and both resilience in sales and digital adoption.

The rest of the paper is structured as follows. Section 2 describes the data. Section 3 explains our hypothesis and empirical strategy. Sections 4 and 5 present the results and robustness checks. Section 6 concludes.

\section{Description of the data}

Our analysis exploits data for Brazil (State of Ceará), Senegal, and Vietnam from the Firm-level Adoption of Technology Survey (FAT) and the COVID-19 Business Pulse Survey (COV-BPS). In this section we describe each survey, summarize the preparation of our data, and provide some descriptive statistics.

\subsection{The FAT data}

The FAT data is a nationally representative survey to measure firm-level technology adoption, which was first implemented in Ceará-Brazil, Senegal, and Vietnam on businesses with 5 or more employees in agriculture, manufacturing, and services (17). This new survey collects data on the 
technologies used more often (from a list of relevant technologies available) in every general and sector-specific business function. The potential technologies associated with each business function follow a ladder of sophistication ranging from the most basic to the most sophisticated (from handwritten processes to Enterprise Resource Planning in the business administration function, for example). In this paper we exploit the firm-level technology sophistication measure for general business functions (GBFs) proposed by (17).

GBFs are tasks common across firms regardless of their sector. They include: business administration, production planning, sourcing and supply chain management, marketing and product development, sales, payments, and quality control. ${ }^{1}$ With the exception of the most basic option (e.g., handwritten processes for business planning), the technologies available to perform GBFs are predominantly digital. Thus, our measure captures the level of sophistication of digital technologies, whenever they are used to perform these tasks. The technology measure for each business function ranges from 1 to 5 to capture the different levels of sophistication of the most frequently used technology for every business function, and then averages these sophistication measures across GBFs within each firm. This average is our measure of pre-pandemic technology sophistication. ${ }^{2}$

The FAT data also includes information about the characteristics of the manager of the firm and about some management practices. Both the human capital of the manager and the management practices potentially determine the capacity of the business to adjust to the COVID-19 shock, and we therefore include these variables in our specifications. The measures of the human capital of the manager are the years of experience in the sector; whether he or she has a post-graduate degree; whether he or she studied abroad; and whether he or she has worked in a multinational or a large business before. The indicators on management practices in the FAT are whether the busi-

\footnotetext{
${ }^{1}$ Business administration corresponds to human resources, finance, and accounting. Appendix A lists each technology associated with each GBF in the FAT survey. See also (17).

${ }^{2}$ The list of key business functions and technologies associated with each of them were developed in collaboration of over 50 sector and technology experts. The FAT survey follows several procedures to minimize bias and measurement errors, both in its design and implementation. Moreover, several ex-post robustness checks for Brazil, Senegal, and Vietnam, including validation of the technology sophistication measures with external data are described by (17). Data were collected through face-to-face interviews with top managers. The survey was implemented by the General Statistics Office (GSO) in Vietnam, by the State Industry Association (FIEC), in Ceará-Brazil, and by Kantar-public, in Senegal.
} 
ness offers incentives to improve performance; the number of key performance indicators (KPI) monitored; the frequency of measurement of KPI; and the time horizon of production targets. ${ }^{3} \mathrm{We}$ follow (18) and combine these four measures into a z-score, which we then include in our linear regressions. ${ }^{4}$

Our specifications control for other pre-pandemic characteristics also available in the FAT: the age, size, and sector of the business; whether the business is an exporter; and whether the business is foreign owned.

\subsection{The COV-BPS data}

The COV-BPS is an initiative of the World Bank Group to track the impact of the COVID-19 pandemic on the private sector across the world (1). In Ceará-Brazil, Senegal, and Vietnam, the COV-BPS was applied on a sub-sample from the FAT. Combined, the FAT and COV-BPS data offer a representative sample of businesses in each country right before and soon after the COVID-19 shock. $^{5}$

Our measure of business performance from the COV-BPS is the reported percentage change in sales in the 30 days prior to the interview relative to the same period of 2019. The COV-BPS also tracks the use of digital technologies to respond to the crisis: whether the business started to use or increased the use of digital platforms since the beginning of the pandemic; whether the business has invested in new equipment, software, or digital solutions since the beginning of the pandemic; whether the share of online sales in total sales increased during the 30 days prior to the interview; and whether the share of employees working from home increased during the 30 days

\footnotetext{
${ }^{3}$ See Appendix A for more details on these questions.

${ }^{4}$ The answers to each question in the management module take values in ascending order starting with 1 for no, none, or never (see Appendix A). We compute the mean and the standard deviation of each indicator in each country (with sampling weights), and use these moments to convert each measure into a z-score. Our management score is the simple average of the four $\mathrm{z}$-scores within a firm.

${ }^{5}$ The FAT sample is a representative sample drawn from the most recent and comprehensive establishment census available in each country (see (17)). The COV-BPS sub-sample was similarly randomly selected to remain nationally representative for Senegal and Vietnam, and representative at the state level in the case of Ceará-Brazil. We provide a description of the sampling strategy in Appendix A. Data collection was conducted by the same agencies that implemented the FAT data in each country. Unless we note otherwise, we do not weight our calculations with sampling weights.
} 
prior to the interview. ${ }^{6}$ Our preferred specifications combine these responses in a single binary indicator that equals 1 when the business reports at least one of the four digital adjustments and 0 if the business did not implement any digital response, but we present results for each digital adjustment separately in our robustness checks.

\subsection{The severity of the COVID-19 shock}

Data for the FAT survey was collected in face-to-face interviews between August and December of 2019 in Ceará-Brazil; between August of 2019 and February of 2020 in Senegal; and between November of 2019 and February of 2020 in Vietnam. Data for the COV-BPS was collected in phone interviews in the early months of the COVID-19 pandemic: between the end of May and the end of July of 2020 in Ceará-Brazil; between the end of April and beginning of May of 2020 in Senegal; and between mid-June and early July of 2020 in Vietnam. Figure A2 in the appendix shows the exact collection period for the COV-BPS in each country with daily average mobility trends around transit stations, which we compute using the data collected by Google in their COVID-19 Community Mobility Reports (19). ${ }^{7}$

Mobility trends likely reflect both, lockdown restrictions and voluntary reductions in interactions out of fear of the virus, and help proxy for the severity of the COVID-19 shock on economic activity (1). In Senegal, average mobility in the period covered in the COV-BPS reached the lowest level recorded for 2020; in Brazil, mobility around transit stations was increasing after a sharp reduction the first weeks of the pandemic; in Vietnam, mobility was almost back to pre-pandemic levels after a v-shape recovery early in the crisis. We include the 30-day mobility average in our estimations to correct for these cross-country differences in the potential severity of the pandemic measures adopted by public authorities at the time of the COV-BPS. Notice the mobility indicator resembles a country fixed effect in our linear regressions because most of the variation occurs across countries, with smaller differences across firms within a country when businesses were

\footnotetext{
${ }^{6}$ The question on digital platforms in the COV-BPS also includes the use of internet, online social media, and specialized apps. Appendix A describes the questions.

${ }^{7}$ In the figure we use average mobility during the 30 days before because our measure of performance in the COV-BPS (the reduction in sales) spans the 30 days prior to the date of the interview.
} 
interviewed at different dates.

One of the salient features of the COVID-19 pandemic has been the heterogeneous impact across industries. We construct a second indicator of potential exposure to the shock for narrowly defined sectors using publicly available aggregate data from the Small Business Pulse Survey in the U.S. (SBPS-US; (20)). We first compute the share of firms in each 3-digit NAICS sector reporting in the SBPS-US that they have experienced a "large overall negative effect from the pandemic" averaging the weekly averages published by the U.S. Census Bureau for the period April-June $2020 .^{8}$ We sort sectors into two categories for potential exposure, low and high, depending on whether the average fraction of firms reporting a large overall negative effect is below or above the U.S. national average (which we obtain for the period April-June 2020 also averaging the weekly averages publicly available). The list of less/more exposed sectors is available in the appendix A (see tables A2 and A3). ${ }^{9}$ In our specifications we include the interaction of this binary variable with fixed effects for broad sector and country.

\subsection{Descriptive statistics}

Table 1 shows the characteristics of our sample across quintiles of the distribution of technology sophistication pre-pandemic (Q1-Q5). Our sample covers around 1,000 businesses. As documented in (17), the right tail of the distribution of technology sophistication in our data is characterized by relatively larger firms; a higher management z-score; and managers comparatively more likely to have a post-graduate degree, to have studied abroad, and to have experience working in a multinational or a large firm.

The average pre-pandemic technology sophistication index in our sample is 1.78 with a standard deviation of 0.62 . The typical business with that level of technology sophistication mostly employs computers with standard software (e.g., Excel) to perform business administration (e.g.,

\footnotetext{
${ }^{8}$ The exact wording of the question is "Overall, how has this business been affected by the COVID-19 pandemic? Select only one: large negative effect; moderate negative effect; little or no effect; moderate positive effect; large positive effect." The SBPS-US is implemented weekly, and the U.S. Census Bureau makes publicly available the estimated fraction of businesses in each response for each question of the survey every week. The averages are available at the national level and for each 3-digit NAICS sector. Estimates are not available for July 2020.

${ }^{9}$ We matched the 3-digit NAICS list with the ISIC classification in our FAT data.
} 
HR processes, finance, and accounting), production and service operations planning, or sourcing and procurement. ${ }^{10}$ They would obtain information from customers mostly through face-to-face interactions or basic online tools (e.g., WhatsApp). Their sales are mostly at the establishment, by phone or email, while their most prevalent payment methods are by check or debit/credit cards. They rely mostly on manual or visual process for quality control. These firms are relatively similar to the median firm (1.71) or the average in the middle $20 \%(\mathrm{Q} 3)$.

In our sample businesses use digital technologies with increasing level of sophistication as we move from Q3 to Q5 (the top 20\%). On the other hand, firms in the bottom 40\% of the technology readiness distribution (Q1 and Q2) mostly rely on manual pre-digital technology to perform their tasks. Although firms in the second quintile (Q2) are already using standard computers for business administration and planning, the method they use more intensively is handwritten processes. ${ }^{11}$

In the early months of the COVID-19 pandemic, more relatively sophisticated businesses reported lower declines in sales and exhibited a higher probability of starting to use or increasing the use of digital technologies. The main digital adjustment was starting to use or increasing the use of digital platforms ( $41 \%$ of the sample) while comparatively lower fractions of businesses invested in new equipment, software, or digital solutions (14\%); increased home-based work (12\%); or reported higher fractions of online sales (13\%). $47 \%$ of the firms in our sample have increased the use of digital technologies for at least one of the four dimensions previously. Still, more sophisticated businesses were relatively more likely to report each individual digital response.

\footnotetext{
${ }^{10} \mathrm{We}$ describe the technologies in a firm with a level of sophistication of 1.78 using the data from the 19 businesses with an index between 1.77 and 1.79 in our sample.

${ }^{11}$ The technologies with increasing levels of sophistication associated with each business function are described in Figure A1.
} 


\begin{tabular}{lrrrrrrr}
\hline & Obs. & Total & Q1 & Q2 & Q3 & Q4 & Q5 \\
\hline (A) FAT: Pre-COVID characteristics & & & & & & & \\
Tech sophistication & 1,063 & 1.78 & 1.10 & 1.36 & 1.73 & 2.06 & 2.77 \\
Brazil & 1,063 & 0.12 & 0.02 & 0.06 & 0.09 & 0.07 & 0.36 \\
Vietnam & 1,063 & 0.45 & 0.01 & 0.31 & 0.67 & 0.79 & 0.52 \\
Senegal & 1,063 & 0.44 & 0.97 & 0.63 & 0.24 & 0.15 & 0.13 \\
Small & 1,030 & 0.52 & 0.71 & 0.71 & 0.50 & 0.45 & 0.24 \\
Medium & 1,030 & 0.26 & 0.21 & 0.21 & 0.30 & 0.29 & 0.30 \\
Large & 1,030 & 0.21 & 0.07 & 0.08 & 0.21 & 0.26 & 0.47 \\
Agriculture & 974 & 0.15 & 0.28 & 0.17 & 0.09 & 0.08 & 0.09 \\
Manufacturing less exposed & 974 & 0.15 & 0.07 & 0.14 & 0.18 & 0.17 & 0.21 \\
Manufacturing more exposed & 974 & 0.18 & 0.20 & 0.15 & 0.18 & 0.16 & 0.19 \\
Services less exposed & 974 & 0.32 & 0.27 & 0.32 & 0.35 & 0.42 & 0.26 \\
Services more exposed & 974 & 0.12 & 0.11 & 0.17 & 0.12 & 0.11 & 0.08 \\
Age 0 to 5 & 1,030 & 0.20 & 0.16 & 0.21 & 0.23 & 0.28 & 0.14 \\
Age 6 to 10 & 1,030 & 0.23 & 0.18 & 0.26 & 0.25 & 0.21 & 0.23 \\
Age 11 to 15 & 1,030 & 0.20 & 0.18 & 0.18 & 0.21 & 0.24 & 0.20 \\
Age 16+ & 1,030 & 0.37 & 0.49 & 0.35 & 0.32 & 0.27 & 0.43 \\
Export & 1,063 & 0.21 & 0.12 & 0.13 & 0.23 & 0.23 & 0.36 \\
Foreign owned & 1,063 & 0.12 & 0.02 & 0.02 & 0.13 & 0.23 & 0.21 \\
Work experience & 1,010 & 17.97 & 18.61 & 16.88 & 15.72 & 15.88 & 22.59 \\
Post-graduate degree & 1,063 & 0.11 & 0.01 & 0.09 & 0.10 & 0.11 & 0.24 \\
Studying abroad & 1,063 & 0.19 & 0.04 & 0.09 & 0.18 & 0.33 & 0.34 \\
Experience in large business & 1,033 & 0.26 & 0.16 & 0.18 & 0.22 & 0.31 & 0.46 \\
Management score & 1,063 & 0.13 & -0.19 & -0.10 & 0.20 & 0.25 & 0.52 \\
\hline
\end{tabular}

(B) COV-BPS: Post-COVID performance and responses

\begin{tabular}{lrrrrrrr} 
Average change in sales (\%) & 1,063 & -45.32 & -53.27 & -49.10 & -40.30 & -38.69 & -44.13 \\
Increased use of digital platforms & 1,052 & 0.41 & 0.12 & 0.36 & 0.51 & 0.53 & 0.58 \\
New investment in digital solutions & 1,058 & 0.14 & 0.10 & 0.15 & 0.12 & 0.13 & 0.21 \\
More work from home & 1,016 & 0.12 & 0.06 & 0.17 & 0.10 & 0.10 & 0.19 \\
More online sales & 706 & 0.13 & 0.07 & 0.18 & 0.10 & 0.09 & 0.20 \\
Increased use of any digital & 1,063 & 0.47 & 0.24 & 0.45 & 0.53 & 0.54 & 0.62 \\
Change in mobility & 1,063 & -33.81 & -56.92 & -41.61 & -22.81 & -17.28 & -27.20 \\
\hline
\end{tabular}

Table 1: Descriptive statistics of FAT and COV-BPS data. Computations do not use sampling weights. Quintiles (Q) are based on technology sophistication pre-COVID-19. Q1 = Bottom 20\%; Q2 = Second quintile; Q3 = Third quintile; Q4 = Fourth quintile; Q5 = Top 20\%. 


\section{Empirical strategy}

Technology readiness pre-pandemic has potentially both direct and indirect effects on the performance of businesses during the COVID-19 shock. We quantify the total effect of technology sophistication pre-crisis estimating both the direct and indirect effects using the treatment effect mediation framework first developed by (11) and more recently described in (12) and (14).

The sophistication of technology pre-pandemic $T$ (the treatment) could directly help businesses to better navigate the shock from COVID-19 and smooth out the drop in sales $Y$ (see the solid arrow in Figure 1). More sophisticated businesses, for example, could better plan production to reduce potential supply chain bottlenecks, or more quickly switch to home-based work given they are more likely to have digital systems in place. Moreover, technology sophistication could also affect the likelihood of responding to the pandemic increasing the use of digital technologies $D$ (the mediator), which in turn would indirectly reduce the impact on sales (see the dashed arrows in Figure 1) by increasing the use of digital platforms to sell their products online, thus reducing the impact of the slowdown in consumer mobility during the shock.

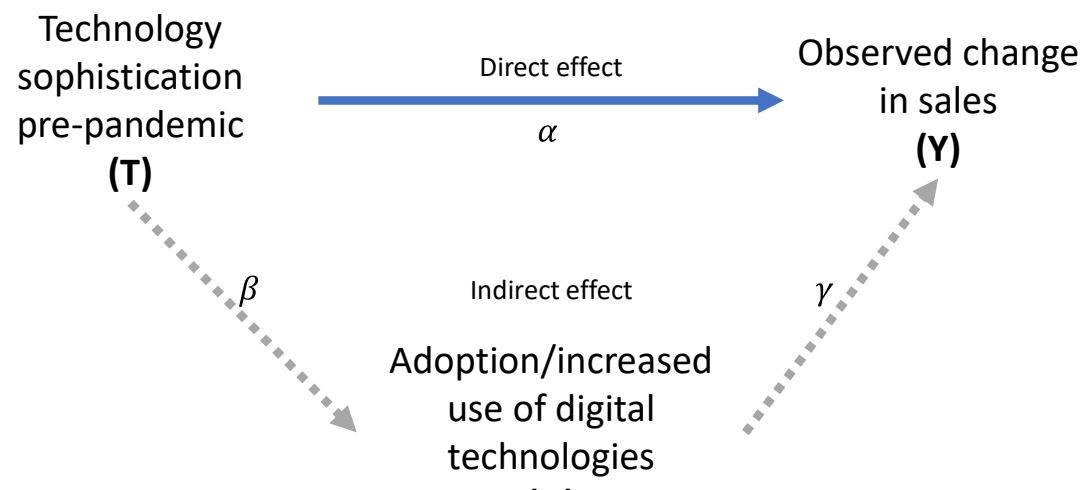

(D)

Figure 1: Direct and indirect effects of technology sophistication pre-pandemic on the performance of firms.

The total observed shock to sales (the outcome) depends then on both technology pre-pandemic and the adoption of additional digital technologies during the shock, which is in turn a function 
of technology sophistication pre-pandemic: $Y(T, D(T))$. Totally differentiating this relationship with respect to $T$ breaks down the total effect on sales from increasing the treatment into a direct impact from increasing $T$ while keeping the mediator $D$ constant, and an indirect effect through the change in $D$ :

$$
\frac{d Y}{d T}=\underbrace{\frac{\partial Y}{\partial T}}_{\text {Direct effect }}+\underbrace{\frac{\partial Y}{\partial D} \frac{d D}{d T}}_{\text {Indirect effect }}
$$

The adoption or increased use of digital technologies during the pandemic can be modelled as a function of technology pre-pandemic:

$$
D_{i}=\nu_{1}+\beta T_{i}+\Phi_{1}^{\prime} X_{i}+\delta_{c s e}+u_{i}
$$

The vector of firm characteristics $X$ includes dummies for the age of the business $(0-5,6-10$, $11-15,16+)$; dummies for size $(5-19 ; 20-99 ; 100+)$; the z-score for the quality of management practices and the measures of human capital of the manager to control for managerial ability; a dummy for whether the business is an exporter; and a dummy for whether the business is foreign owned. To control for the severity of the shock, we include in $X$ the average mobility around transit stations the 30 days prior to the interview as reported in Google mobility reports $(1,19)$, in addition to the country-sector-exposure fixed effects $\delta_{c s e}$. These fixed effects correspond to the interaction of the dummies for country (Brazil, Senegal, and Vietnam), sector (Agriculture, Manufacturing, and Services), and the measure of pandemic exposure described above using the SBPS-US (Low, High).

The shock to sales during the crisis varies linearly with both technology sophistication prepandemic and the dummy for whether the business increased the use of digital technology to respond to the shock (with no interaction between the two):

$$
Y_{i}=\nu_{2}+\alpha T_{i}+\gamma D_{i}+\Phi_{2}^{\prime} X_{i}+\delta_{c s e}+v_{i}
$$

Our identification is based on the assumptions that unobservables $u$ and $v$ are not correlated 
with one another nor with the covariates in specifications (2) and (3) above. ${ }^{12}$ Under these assumptions, the total effect of technology pre-pandemic on sales (the total treatment effect) is simply $\alpha+\beta \gamma$, which we obtain estimating using ordinary least squares each linear model separately. In our baseline, we use the technology index in levels to estimate average effects.

Our econometric model can be easily adapted to explore the presence of non-linearities by allowing $\alpha$ and $\beta$ to vary by quintiles of the distribution of technology sophistication. In this setting, the total effect of technology sophistication for firms in the $k^{\text {th }}$ pre-pandemic technology sophistication quintile is $\alpha_{k}+\beta_{k} \gamma$. We report our non-linear results relative to the bottom quintile.

\section{Estimation results: indirect and direct effects of technology sophistication}

In this section we present our estimates for the indirect, direct, and total treatment effect of technology sophistication pre-pandemic on the change in monthly sales early on in the COVID-19 pandemic. Table 2 summarizes our main results, followed by the interpretation and discussion grouped by indirect, direct, and total effects. The full set of results from least squares is available in the Appendix B. We find positive indirect and direct treatment effects. The direct effect is significantly larger but the magnitude of both effects increases with pre-pandemic technology sophistication.

\footnotetext{
${ }^{12}$ We assume that COVID-19 shock was an unexpected event that did not affect the decision of firms with respect to $T_{i}$ and we control for other factors, such as management and managerial practice characteristics, as well as the sectoral heterogeneity in the severity of the shock, which could be potential confounders.
} 


\begin{tabular}{|c|c|c|c|c|c|}
\hline & $\begin{array}{c}(1) \\
\text { Marginal prob } \\
\text { of additional } \\
\text { digital } \\
\text { technology } \\
\widehat{\beta}\end{array}$ & $\begin{array}{c}(2) \\
\text { Marginal effect } \\
\text { of additional } \\
\text { digital tech on } \\
\text { sales (pp) } \\
\widehat{\gamma}\end{array}$ & $\begin{array}{c}(3) \\
\text { Indirect effect } \\
\text { on sales }(\mathrm{pp}) \\
\widehat{\beta} \times \widehat{\gamma}\end{array}$ & $\begin{array}{c}(4) \\
\text { Direct effect on } \\
\text { sales (pp) }\end{array}$ & $\begin{array}{c}(5) \\
\text { Total effect of } \\
\text { technology } \\
\text { sophistication } \\
(\widehat{\beta} \times \widehat{\gamma})+\widehat{\alpha}\end{array}$ \\
\hline Average & $\begin{array}{c}0.17 * * * \\
(0.04)\end{array}$ & $\begin{array}{c}6.6 * * * \\
(2.2)\end{array}$ & 1.1 & $\begin{array}{l}5.4^{*} \\
(2.8)\end{array}$ & 6.5 \\
\hline Q2 & $\begin{array}{c}0.25 * * * \\
(0.05)\end{array}$ & & 1.5 & $\begin{array}{c}3.4 \\
(3.8)\end{array}$ & 5.0 \\
\hline Q3 & $\begin{array}{c}0.35 * * * \\
(0.06)\end{array}$ & $6.2 * * *$ & 2.2 & $\begin{array}{c}9.9 * * \\
(4.3)\end{array}$ & 12.1 \\
\hline Q4 & $\begin{array}{c}0.34 * * * \\
(0.07)\end{array}$ & (2.3) & 2.1 & $\begin{array}{l}9.7 * * \\
(4.7)\end{array}$ & 11.8 \\
\hline Q5 & $\begin{array}{c}0.37 * * * \\
(0.07)\end{array}$ & & 2.3 & $\begin{array}{c}11.4 * * \\
(5.1)\end{array}$ & 13.7 \\
\hline
\end{tabular}

Table 2: Direct and indirect effects of technology pre-pandemic on the percentage change in sales. $* * * \mathrm{p}<0.01, * * \mathrm{p}<0.05, * \mathrm{p}<0.1$. Standard errors in parenthesis. Column 1 reports estimated coefficients on technology sophistication from ordinary least squares in a linear regression where the dependent variable is whether the business increased the use of digital technology during the crisis (Equation 2), using the technology index in levels (Average) and in quintiles in an alternative specification (Q2-Q5; the omitted category is the bottom 20\%). Column 2 show the estimated coefficient on whether the business increased the use of digital solutions during the crisis in a linear regression where the dependent variable is the reported percentage change in sales relative to the same period of 2019 (Equation 3). Column 4 shows the coefficient on technology sophistication in the same linear regression. Column 3 is the total indirect effect (the product of columns 1 and 2), whereas column 4 shows the total effect of technology pre-pandemic (the sum of the indirect and direct effect). The linear regressions control for the age of the business $(0-5,6-10,11-15,16+)$; size $(5-19 ; 20-99 ; 100+)$; the z-score for management practices and the measures of human capital of the manager; a dummy for whether the business is an exporter; a dummy for whether the business is foreign owned; average mobility around transit stations the 30 days prior to the interview; and country, sector, exposure, and country-sector-exposure fixed effects. Full set of results available in the Appendix B.

\section{The indirect effect}

Firms with higher levels of technology pre-pandemic were significantly more likely to start or increase the use of digital technologies during the COVID-19 crisis. On average, a change in one 
standard deviation in pre-pandemic technology sophistication is associated with an increase of 10 percentage points (pp) in the likelihood of starting or increasing the use of digital technology. The least squares estimate for a one unit increase in the technology index ( $\beta$ in Equation 2$)$ amounts to 17 pp, a statistically significant coefficient (see Table 2, column 1). ${ }^{13}$

Table 2 also shows the estimates for the effect of technology sophistication on the likelihood of adopting digital solutions in the specification with quintiles. The marginal likelihood rapidly increases with technology sophistication in the left tail of the distribution and slows down after the third quantile. While businesses in the second quintile of technology sophistication were $25 \mathrm{pp}$ more likely to start or increase the use of digital solutions relative to the bottom $20 \%$, the additional likelihood for businesses in quintiles 3-5 is at least $35 \mathrm{pp}$.

In turn, adopting digital technology during the crisis is associated with percentage changes in sales 6.6 points higher on average, and $6.2 \mathrm{pp}$ when using quintiles for the tech sophistication index instead of levels ( $\gamma$ in Equation 3) (see Table 2, column 2). The total indirect effect of technology pre-pandemic on sales averages $1.1 \mathrm{pp}(0.66 \mathrm{pp}$ with an increase in tech sophistication of one standard deviation), but increases to $1.5 \mathrm{pp}$ when comparing businesses in the second quintile to those in the bottom $20 \%$, and to 2.3 pp among the most technologically sophisticated firms (see Table 2, column 3).

\section{The direct effect}

The direct impact of technology sophistication pre-pandemic on sales ( $\alpha$ in Equation 3) is significantly larger than the indirect effect through the adoption of digital solutions. On average, increasing technology sophistication in one standard deviation is associated with sales around 3.1 pp higher relative to the same period of 2019. The least squares estimate for a one unit increase in the technology index is $5.4 \mathrm{pp}$ (with a p-value of 5.1\%), and ranges from $3.4 \mathrm{pp}$ when comparing

\footnotetext{
${ }^{13}$ Firms with one standard deviation (0.62 points) higher than the average technology sophistication index (1.78) tend to rely on specialized software to perform business administration, standard software for production planning and sourcing, online chat or Internet to interact with costumers, debit/credit card and online payment, and use of computers for quality control. Firms with 1 point higher than the average technology sophistication index (2.78) tend to be very close to the frontier on performing tasks such as business administration and planning (e.g., use ERP systems) and use basic to more sophisticated digital technologies in all other GBFs.
} 
the second quintile of the distribution to the bottom $20 \%$ (a difference that is not statistically significant), to 11.4 among the most sophisticated businesses, which we show in Table 2, column (4).

\section{The total treatment effect of technology sophistication}

Both direct and indirect effects on sales are positive and their magnitude increases with prepandemic technology sophistication. The resulting total effect averages $6.5 \mathrm{pp}$ (3.8 pp for an increase of one standard deviation in technology sophistication), and ranges from $5 \mathrm{pp}$ when comparing businesses in the second quintile to those in the bottom $20 \%$, to almost $14 \mathrm{pp}$ for businesses in the fifth quintile (see Table 2, column 5). The direct effect accounts for most of the impact of technology sophistication pre-pandemic, as we show in Figure 2, since the impact of additional technology adoption on sales (6.6 pp on average) is mediated by an estimated probability of additional adoption that increases with technology sophistication but averages only $37 \%$ among the most sophisticated firms.

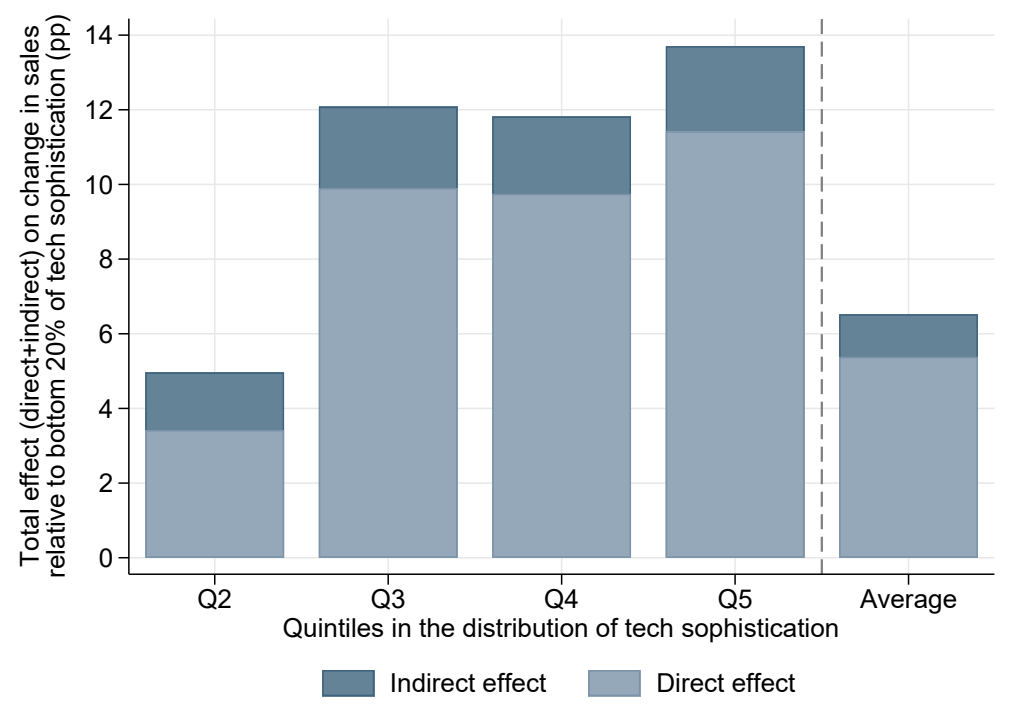

Figure 2: Indirect, direct, and total effects of technology pre-pandemic on the percentage change in sales. Percentage change in sales relative to the same period of 2019. See Table 2 for details on the computations of the direct and indirect effects.

The only other covariate with statistically significant indirect and direct effects on the shock to 
sales, in addition to technology sophistication, is the size of the firm (see Tables B1, B2, B3, and B4 in the appendix). Whether the manager has a post-graduate degree has an indirect effect on performance during the pandemic, but the direct effect is not statistically significant. In contrast, the dummy for whether the business is part of a multi-national has a direct effect but the indirect effect is not statistically significant. The z-score for management practices is not statistically significant in the equation for additional use of digital technology during the pandemic (the mediator) nor in the equation for the shock to sales.

\section{Robustness checks}

Our estimations combine the four digital responses available in the COV-BPS data in a single binary indicator. In this section we show results for each digital adjustment separately. We also present results for the indirect effect using matching estimators.

\subsection{The treatment effect under different mediators}

Our estimation results are robust to different definitions of the mediator. Figure 3 shows estimates for the direct and indirect effects using each potential digital response as an indirect channel for the effect of technology sophistication. The total effect remains close to $6.5 \mathrm{pp}$ when the response is the additional use of digital platforms or the new investment in equipment, software, or digital solutions. When the response is more home-based work the effect increases in $1 \mathrm{pp}$, and in close to $2 \mathrm{pp}$ when we consider the higher share of online sales. 


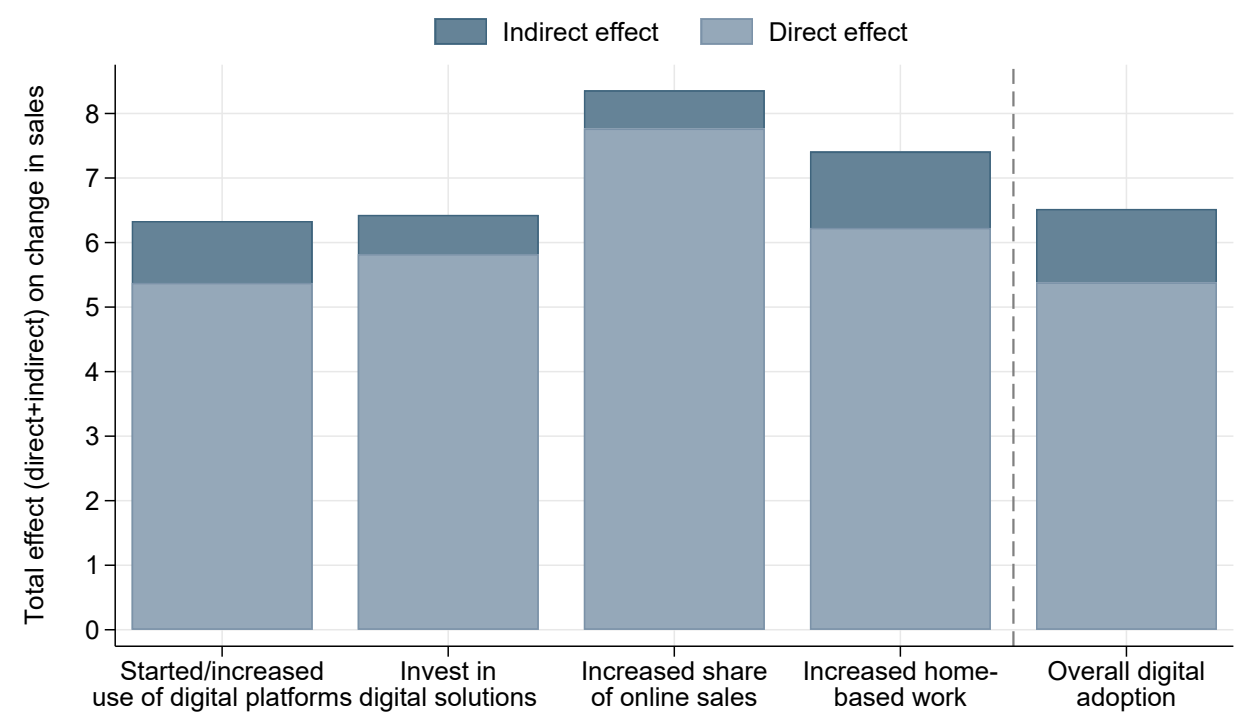

Figure 3: Indirect, direct, and total effects of technology pre-pandemic on the percentage change in sales. Differences across digital responses. Results from estimating the model separately for each digital adjustment. Full set of results available in the appendix B. Percentage change in sales relative to the same period of 2019.

\subsection{Matching estimations for the indirect effect}

One potential caveat of the estimates of the indirect effect above is that other factors different from technology readiness may explain both adoption of digital technologies and performance through COVID-19. To minimize this risk, we estimate the indirect effect matching on existing observable characteristics pre-pandemic comparing businesses that adopted digital technology during the pandemic to a counterfactual with a similar likelihood of adoption or with similar characteristics. ${ }^{14}$ Table 3 shows estimates for the effect of additional digital technology adoption on the shock to sales $(\gamma)$ using both propensity score (PSM) and nearest-neighbor matching (NNM). ${ }^{15}$ Unlike least squares, matching estimators compare samples that are comparatively balanced in their composition, based on observable characteristics. ${ }^{16}$

Specification in Equation 2 is used to estimate the propensity score using a Probit model, and

\footnotetext{
${ }^{14}$ Our identification assumption is that selection in digital response $D_{i}$ is based on observable characteristics and that we control for the variables that influence treatment assignment and potential outcomes simultaneously.

${ }^{15}$ Table B5 and Table B6 of appendix B show the PSM and NMM estimates.

${ }^{16}$ The balance on observable characteristics (common support) ensures that firms with similar observable characteristics have a positive probability of being both participants and non-participants (21).
} 
use a caliper of 0.03 to match observations. The effect on sales increases from $6.6 \mathrm{pp}$ with least squares to $7.6 \mathrm{pp}$. with PSM. Under this alternative estimate for $\gamma$ the indirect effect of technology sophistication would increase to 1.3 and the total effect to 6.7. ${ }^{17}$

In the NNM specification, we pair observations exactly on country, major sector (agriculture, manufacturing, services), and exposure to the COVID-19 shock (the dummy indicator), and use Mahalanobis distance to find the nearest neighbors on the remaining covariates (22). ${ }^{18}$ The estimated average effect of additional digital adoption increases to $8.8 \mathrm{pp}$ for a total indirect effect of technology sophistication of 1.5 and a total effect of 6.9 (Table 3).

Thus, the indirect effect of technology readiness via the increase in the use of digital technologies is robust across specifications, and ranges between 1.1 and 1.5.

\begin{tabular}{lccc}
\hline & OLS & PSM & NNM \\
\hline Marginal effect of additional digital tech on sales $(\mathrm{pp}) \widehat{\gamma}$ & $\begin{array}{c}6.6^{* * *} \\
(2.2)\end{array}$ & $\begin{array}{c}7.6^{* * * *} \\
(2.8)\end{array}$ & $\begin{array}{c}8.8^{* * * *} \\
(2.8)\end{array}$ \\
\hline Indirect effect of tech sophistication on sales $(\mathrm{pp}) \widehat{\beta} \times \widehat{\gamma}$ & 1.1 & 1.3 & 1.5 \\
\hline
\end{tabular}

Table 3: Least squares and matching estimates for the effect of additional digital adoption during the pandemic on the percentage change in sales. $* * * \mathrm{p}<0.01, * * \mathrm{p}<0.05, * \mathrm{p}<0.1$. Standard errors in parenthesis. Full set of results available in the appendix B. Percentage change in sales the 30 days prior to the interview relative to the same period of 2019.

\section{Concluding remarks}

This paper presents new evidence on the importance of technology readiness on firm resilience during the COVID-19 pandemic. We show that the pre-pandemic level of technology sophistication had both direct and indirect effects on firm sales in the early stage of shock. The indirect channel operates through firms speeding up the introduction of or increasing the use of digital technologies in response to the crisis. The results also suggest heterogeneity across firms: those in

\footnotetext{
${ }^{17}$ Figure B1 of the appendix shows the distribution of propensity score for treated (increase the use of any digital) and untreated groups. Table B7 and Table B8 of Appendix B compare the differences across variables between treated and untreated groups for the original (unbalanced) and the balanced sample matched through PSM.

${ }^{18}$ We follow the Mahalanobis nearest-neighbor algorithm implemented in STATA where the distance between the covariates of individuals $i$ and $j$ is $\left\{\left(\mathbf{x}_{i}-\mathbf{x}_{j}\right)^{\prime} \mathbf{S}^{-1}\left(\mathbf{x}_{i}-\mathbf{x}_{j}\right)\right\}^{12}$, with the variance-covariance matrix of the covariates in the sample as the weighting matrix $\mathbf{S}$.
} 
the bottom quintile of technology readiness (i.e. firms that were rarely adopting any digital technology) were significantly less likely to adjust and were harder hit by the shock (controlling for observable characteristics such as size, sector, region, and management quality).

Our results suggest that an important additional benefit from upgrading technology might be an increase in the resilience of businesses to shocks. Given the increasing interest by government agencies in implementing technology upgrading programs to support digitization, it is important to emphasize this additional benefit in order to increase the incentives to upgrade and maximize program take up.

\section{References}

1. M. C. Apedo-Amah, et al., Businesses through the covid-19 shock: Firm-level evidence from around the world, Policy Research Working Paper 9434, World Bank (2020).

2. A. W. Bartik, et al., The impact of covid-19 on small business outcomes and expectations, Proceedings of the National Academy of Sciences 117, 17656 (2020).

3. R. Dai, J. Hu, X. Z. Zhang, The impact of coronavirus on china's smes: Findings from the enterprise survey for innovation and entrepreneurship in china, Working paper, Center for Global Development (2020).

4. J. E. Humphries, C. Neilson, G. Ulyssea, The evolving impacts of covid-19 on small businesses since the cares act, Cowles Foundation Discussion Paper No. 2230 (2020).

5. A. Adams-Prassl, T. Boneva, M. Golin, C. Rauh, Inequality in the impact of the coronavirus shock: Evidence from real time surveys, Journal of Public Economics 189, 104245 (2020).

6. R. W. Fairlie, The impact of covid-19 on small business owners: Evidence of early-stage losses from the april 2020 current population survey, Working Paper 27309, National Bureau of Economic Research (2020). 
7. R. W. Fairlie, The impact of covid-19 on small business owners: The first three months after social-distancing restrictions, Working Paper 27462, National Bureau of Economic Research (2020).

8. X. Cirera, et al., Policies to support businesses through the covid-19 shock: A firm level perspective, The World Bank Research Observer 36, 41 (2021).

9. J. Van Reenen, A. Valero, How is covid-19 affecting firms' adoption of new technologies?, Economics Observatory (2021).

10. L. Bellmann, et al., Digitalisierungsschub in firmen während der corona-pandemie, Working Paper, Luxembourg Institute for Socio-Economic Research (LISER) (2021).

11. R. M. Baron, D. A. Kenny, The moderator-mediator variable distinction in social psychological research: Conceptual, strategic, and statistical considerations., Journal of personality and social psychology 51, 1173 (1986).

12. K. Imai, L. Keele, T. Yamamoto, Identification, inference and sensitivity analysis for causal mediation effects, Statistical science 25, 51 (2010).

13. J. J. Heckman, R. Pinto, Econometric mediation analyses: Identifying the sources of treatment effects from experimentally estimated production technologies with unmeasured and mismeasured inputs, Econometric reviews 34, 6 (2015).

14. V. Celli, Causal mediation analysis in economics: Objectives, assumptions, models, Journal of Economic Surveys (2021).

15. J. J. Bai, E. Brynjolfsson, W. Jin, S. Steffen, C. Wan, Digital resilience: How work-fromhome feasibility affects firm performance, Working Paper 28588, Tech. rep., National Bureau of Economic Research (2021).

16. P.-H. Hsu, H.-H. Lee, S.-C. Peng, L. Yi, Natural disasters, technology diversity, and operating performance, Review of Economics and Statistics 100, 619 (2018). 
17. X. Cirera, D. A. Comin, M. Cruz, K. M. Lee, Anatomy of technology in the firm, National Bureau of Economic Research, Working Paper, n. 28080.

18. N. Bloom, J. Van Reenen, Why do management practices differ across firms and countries?, Journal of economic perspectives 24, 203 (2010).

19. Google, Google covid-19 community mobility reports, https://www.google.com/covid19/mobility/ (2020). (accessed 2020-Aug-07).

20. C. Buffington, et al., Measuring the effect of covid-19 on us small businesses: The small business pulse survey, Working Paper CES-20-16, U.S. Census Bureau, Center for Economic Studies, Tech. rep. (2020).

21. M. Caliendo, S. Kopeinig, Some practical guidance for the implementation of propensity score matching, Journal of economic surveys 22, 31 (2008).

22. A. Abadie, G. W. Imbens, Bias-corrected matching estimators for average treatment effects, Journal of Business \& Economic Statistics 29, 1 (2011).

\section{Acknowledgments}

We have greatly benefited from discussions with Miriam Gensowski, Denis Medvedev, Trang Thu Tran, Stephen Yeo, and Mark Dutz. We also thank our colleagues at the World Bank, the ANSD (Senegal), the GSO (Vietnam), and the Industry Association of Ceará (Brazil) who supported the collection of the survey data. All errors are our own. The views expressed in this article are solely those of the authors and do not necessarily reflect the views of the World Bank, its Executive Directors, or the countries they represent. 


\section{Supplementary materials}

\section{Appendix A - Data referred to in Section 2}

\section{A1. General business functions in the FAT survey}

Figure A1 lists the general business functions included in FAT and the technologies associated with them. The General Business Support Functions (GBFs) are commonly available across all firms and are therefore comparable across firms, sectors, and countries. The GBFs are: 1) Business Administration; 2) Production Planning; 3) Sourcing and Procurement; 4) Marketing and Customer Information; 5) Sales; 6) Methods of Payment; and 7) Quality Control. The technologies associated with each business function follow a ladder of sophistication that goes from the most basic to the most sophisticated level. This ranking was developed in consultation with several sector experts. ${ }^{19}$
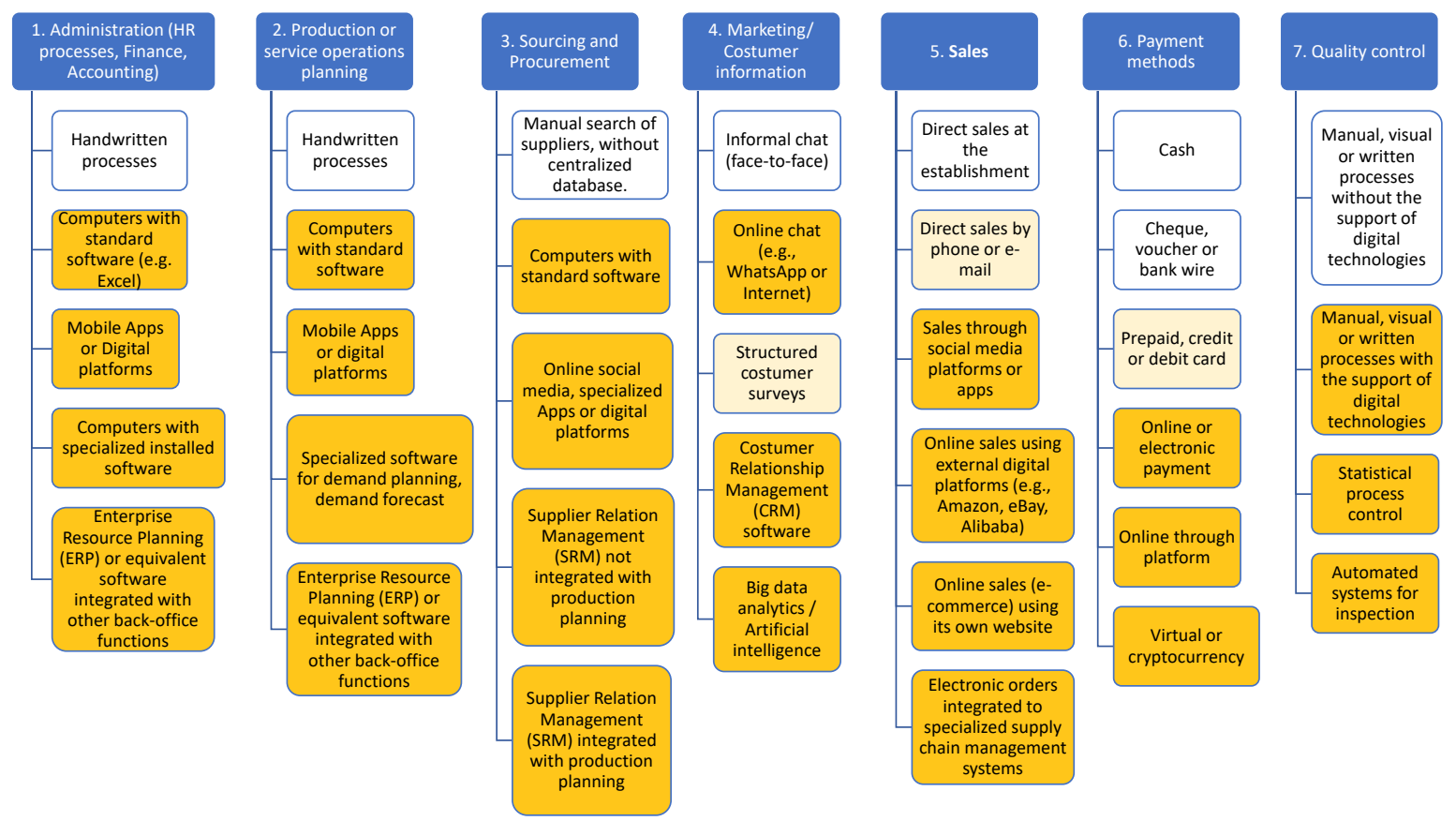

Figure A1: General Business Functions (GBF) Technologies in the FAT. Digital technologies are highlighted in yellow. Light yellow boxes refers to technologies that can rely directly or indirectly on digital (e.g., consumer surveys conducted online, email for sales, or use of credit card through digital sales' platforms).

\footnotetext{
${ }^{19} \mathrm{~A}$ full description of the FAT survey and the technology sophistication index we use can be found in (17).
} 
Technology sophistication measure (Technology readiness) The Pre-pandemic technology index used in this paper reflects the sophistication of the most widely used technology in a business function, as described in Figure A1. Following (17), based on the experts' assessment, we order the technologies in each function $f$ according to their sophistication, and assign each a rank $r_{f} \in$ $1,2, \ldots, R_{f}$, from least to most advanced. Because several technologies may have the same sophistication, the highest rank in a function $R_{f}$ may be smaller than the number of possible technologies $N_{f}$. We define the relative rank of a technology as $\hat{r}_{f}=\frac{r_{f}-1}{R_{f}-1}$. Note that $\hat{r}_{f} \in[0,1]$. The technology sophistication of business function $f$ in firm $j$ is a monotonic increasing function of the relative rank of the most widely used technology of firm $j$ in function $f\left(\hat{r}_{f, j}\right)$. For example, our baseline sophistication measure is

$$
s_{f, j}=1+4 * \hat{r}_{f, j} .
$$

The technology sophistication measure is scaled between 1 and 5. For example, if the firm is mostly using a frontier technology (e.g., ERP for business administration), it takes the value of 5, while if it is mostly using the most rudimentary technology (e.g., handwritten processes for business administration), it takes the value of 1 . The information of the average index and its distribution across quintiles, combined with the standard deviation, provided in Table 1 may provide a good intuition of the specific technologies used by those firms. For example, the average of 1.1 for firms in Q1 with a standard deviation of 0.02 suggests that these firms are mostly relying on manual methods to perform GBFs with little variation among them. (17) provides several robustness checks to show the measure is robust to alternative plausible cardinalizations of the ordinal rankings.

\section{A2. The FAT and COV-BPS questionnaires}

The management questions and the questions on skill of the top manager in the FAT are:

- Does this establishment provide formal incentives for workers in the form of money, gift, or recognition to suggest and/or use better ways to produce goods or provide services? Yes/No. 
- In the year 2019, how many key performance indicators were monitored at this establishment? 1-2/3-9/10+/None.

- In the year 2019, how frequently were the key performance indicators reviewed by managers at this establishment? Yearly/Quarterly/Monthly/Weekly/Daily/Hourly or more frequently/Never.

- In the year 2019, what best describes the time frame of production targets at this establishment? Short-term/Long-term/Both/None.

- How many years of experience working in this sector does the top manager have?

- What is the highest level of education of the top manager? Primary school/Secondary school/Complete high school/College degree/Post-grad.

- Did the top manager study abroad for more than a month? Yes/No.

- Does the CEO or top manager of this establishment have previous experience working in a multinational or a national firm with more than 50 employees in the same sector? Yes/No.

The COV-BPS questions on sales and digital responses are:

- Change in sales: Comparing this establishment sales for the last 30 days (before this interview) with the same period of 2019 , did the sales increase/remain the same/decrease, and by how much?

- Use of digital platforms: Has this establishment started using or increased the use of internet, online social media, specialized apps, or digital platforms in response to the COVID-19 outbreak? Yes, it started/Yes, it increased/No.

- Investment in digital solutions: Has this establishment invested in any new equipment, software or digital solution in response to COVID-19? Yes/No.

- Online sales: In the last 30 days, has the share of sales of this establishment using digital platforms increased or decreased? Increase/Decrease/No change. 
- Home-based work: In the last 30 days, has the share of workers working from home increased or decreased? Increase/Decrease/No change.

\section{A3. Sampling frame of the FAT and COV-BPS Surveys}

For both Firm-level Adoption of Technology Survey (FAT) and Business Pulse Survey (COVBPS), the sampling strategy was based on the latest establishment census available from national statistical agencies or administrative business register. The sampling frame for the state of Ceará in Brazil was the 2017 Relação Anual de Informações Sociais (RAIS) managed by the Ministry of Economy (MoE); the 2018 Establishment Census from the General Statistical Office (GSO) for Vietnam; and the 2016 Recensement Général des Entreprises (RGE) from the Agence Nationale de la Statistique et de la Démographie (ANSD) in Senegal. Each database covers all registered establishments operating in each country.

(17) drew a nationally representative sample of establishments with 5 or more employees in agriculture, manufacturing, and services. The sample was randomly selected based on three strata: region, size, and sector. The FAT data for the State of Ceará in Brazil, Vietnam, and Senegal were collected between August 2019 and February 2020, and most observations were collected before December 2019. For Ceará-Brazil, Senegal, and Vietnam, the BPS survey was implemented on a nationally representative sub-sample of FAT data. This data was collected between April and July 2020.

The FAT-BPS data covers around 1,000 businesses both before and after the COVID-19 pandemic crisis. Table A1 provides the sample size of the linked FAT-COV-BPS data and the interview periods in each country. Figure A2 shows the interview period of the COV-BPS survey in each country and the average mobility trend as a proxy for the severity of the COVID-19 shock over this period.

\begin{tabular}{l|c|c|c}
\hline & Sample size & FAT & COV-BPS \\
\hline Brazil-Ceara & 124 & $08 / 2019-12 / 2019$ & $05 / 26 / 20-07 / 24 / 20$ \\
Senegal & 464 & $08 / 2019-02 / 2020$ & $04 / 28 / 20-05 / 08 / 20$ \\
Vietnam & 475 & $11 / 2019-02 / 2020$ & $06 / 12 / 20-07 / 07 / 20$ \\
\hline
\end{tabular}

Table A1: Sample size and interview dates for the FAT and BPS surveys. 


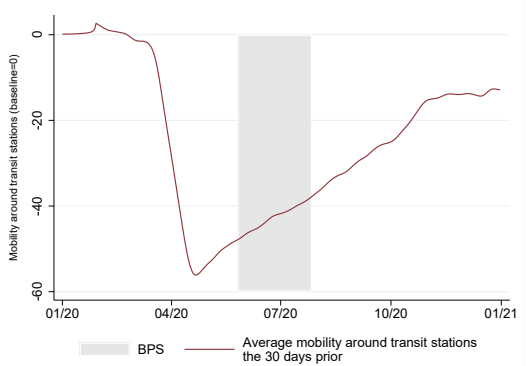

(a) Brazil.

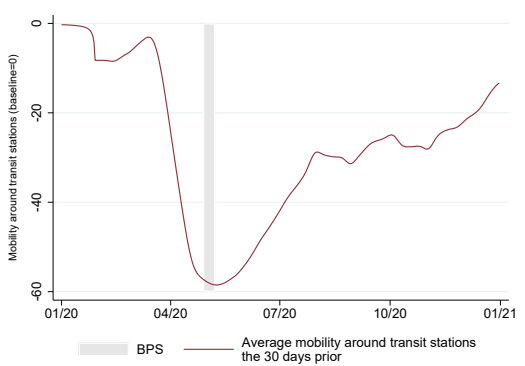

(b) Senegal.

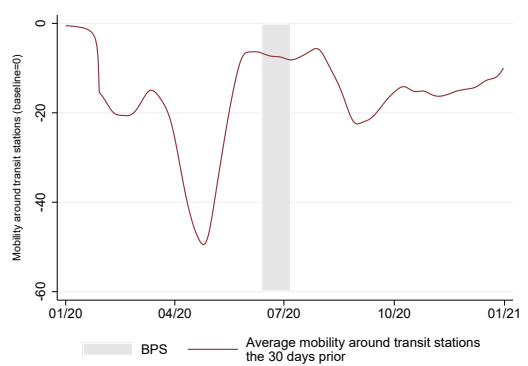

(c) Vietnam.

Figure A2: Timing of the COV-BPS in the context of the COVID-19 mobility shock in each country. We first compute the average for the daily mobility trends around transit stations across locations in each country from Google's COVID-19 Community Mobility Reports (19), and then smooth the time series using 7-day moving averages. The red line shows for each date the average of the past 30 days of this smoothed out time series. 


\section{A4. List of less exposed and more exposed ISIC-3 sectors}

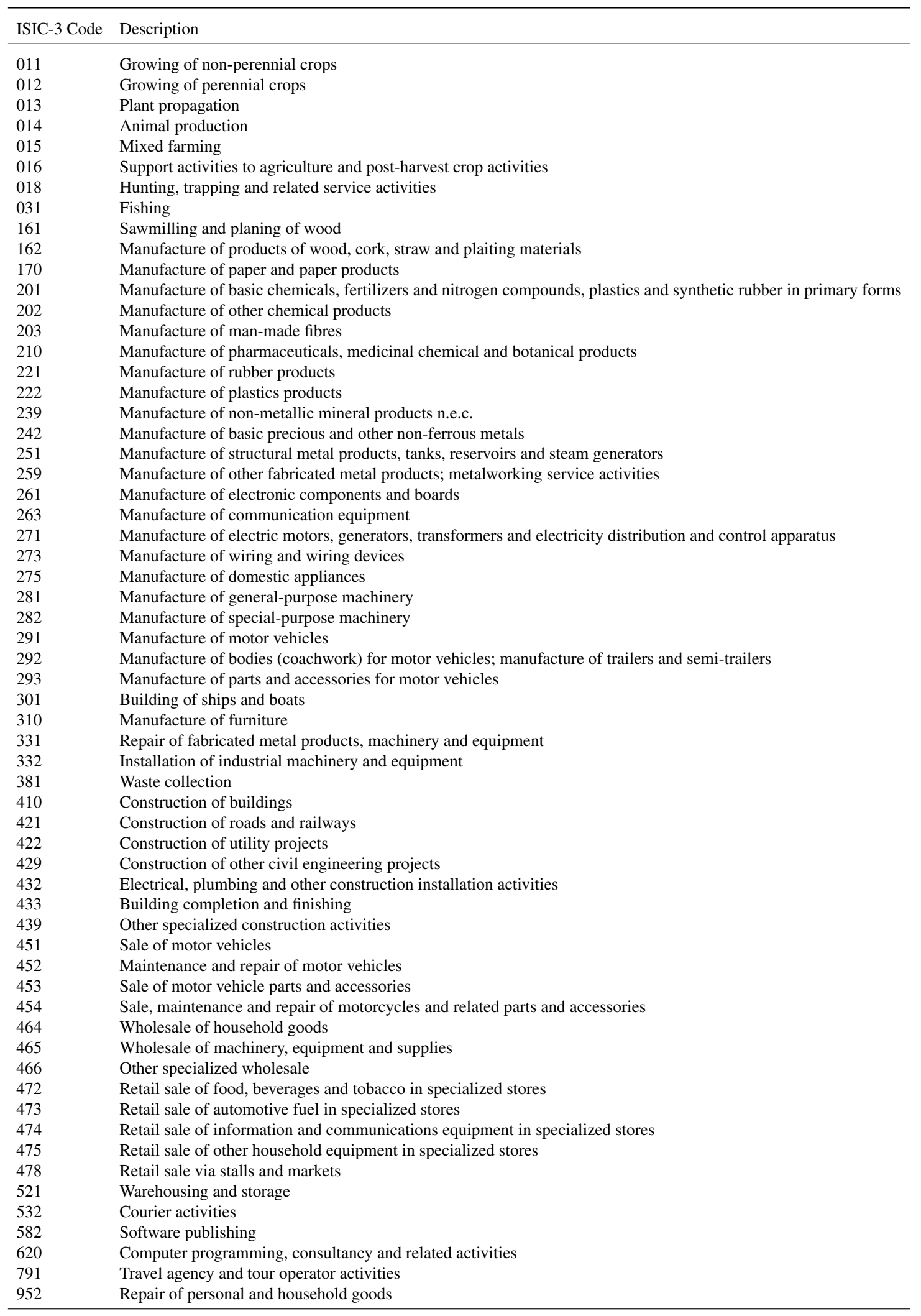

Table A2: ISIC-3 sectors less exposed to the COVID-19. 
ISIC-3 Code Description

$101 \quad$ Processing and preserving of meat

102 Processing and preserving of fish, crustaceans and molluscs

103 Processing and preserving of fruit and vegetables

$105 \quad$ Manufacture of dairy products

106

107

Manufacture of grain mill products, starches and starch products

Manufacture of other food products

Manufacture of prepared animal feeds

Manufacture of beverages

Spinning, weaving and finishing of textiles

Manufacture of other textiles

Manufacture of wearing apparel, except fur apparel

Manufacture of knitted and crocheted apparel

Tanning and dressing of leather; manufacture of luggage, handbags, saddlery and harness; dressing and dyeing of fur Manufacture of footwear

Printing and service activities related to printing

Manufacture of jewellery, bijouterie and related articles

Manufacture of games and toys

Demolition and site preparation

Wholesale of agricultural raw materials and live animals

Wholesale of food, beverages and tobacco

Retail sale in non-specialized stores

Retail sale of cultural and recreation goods in specialized stores

Retail sale of other goods in specialized stores

Other land transport

Sea and coastal water transport

Inland water transport

Support activities for transportation

Short term accommodation activities

Camping grounds, recreational vehicle parks and trailer parks

Restaurants and mobile food service activities

Event catering and other food service activities

Wireless telecommunications activities

Table A3: ISIC-3 sectors more exposed to the COVID-19. 


\section{Appendix B - Results referred to in Sections 4 and 5}

\begin{tabular}{|c|c|c|c|c|c|}
\hline & $\begin{array}{c}(1) \\
\text { Increased } \\
\text { use of } \\
\text { digital } \\
\text { platforms }\end{array}$ & $\begin{array}{c}(2) \\
\text { New } \\
\text { investment } \\
\text { in digital } \\
\text { solutions }\end{array}$ & $\begin{array}{c}(3) \\
\text { More } \\
\text { work from } \\
\text { home }\end{array}$ & $\begin{array}{c}(4) \\
\text { More } \\
\text { online } \\
\text { sales }\end{array}$ & $\begin{array}{c}(5) \\
\text { Increased } \\
\text { use of } \\
\text { digital } \\
\text { tech }\end{array}$ \\
\hline Tech Sophistication & $\begin{array}{c}0.14 * * * \\
(0.04)\end{array}$ & $\begin{array}{c}0.08 * * * \\
(0.03)\end{array}$ & $\begin{array}{c}0.10 * * * \\
(0.03)\end{array}$ & $\begin{array}{c}0.04 \\
(0.03)\end{array}$ & $\begin{array}{c}0.17 * * * \\
(0.04)\end{array}$ \\
\hline Medium & $\begin{array}{c}0.03 \\
(0.04)\end{array}$ & $\begin{array}{c}0.10 * * * \\
(0.03)\end{array}$ & $\begin{array}{l}0.04 * \\
(0.02)\end{array}$ & $\begin{array}{c}0.02 \\
(0.03)\end{array}$ & $\begin{array}{c}0.04 \\
(0.04)\end{array}$ \\
\hline Large & $\begin{array}{c}0.10 * * \\
(0.05)\end{array}$ & $\begin{array}{c}0.12 * * * \\
(0.04)\end{array}$ & $\begin{array}{c}0.06 * * \\
(0.03)\end{array}$ & $\begin{array}{c}0.03 \\
(0.04)\end{array}$ & $\begin{array}{l}0.08 * \\
(0.05)\end{array}$ \\
\hline Age 6 to 10 & $\begin{array}{l}-0.03 \\
(0.05)\end{array}$ & $\begin{array}{c}0.01 \\
(0.03)\end{array}$ & $\begin{array}{l}-0.00 \\
(0.03)\end{array}$ & $\begin{array}{l}-0.05 \\
(0.03)\end{array}$ & $\begin{array}{c}0.06 \\
(0.05)\end{array}$ \\
\hline Age 11 to 15 & $\begin{array}{l}-0.03 \\
(0.05)\end{array}$ & $\begin{array}{l}-0.03 \\
(0.03)\end{array}$ & $\begin{array}{l}-0.03 \\
(0.03)\end{array}$ & $\begin{array}{l}-0.05 \\
(0.04)\end{array}$ & $\begin{array}{l}-0.00 \\
(0.05)\end{array}$ \\
\hline Age $16+$ & $\begin{array}{l}-0.01 \\
(0.05)\end{array}$ & $\begin{array}{c}0.00 \\
(0.04)\end{array}$ & $\begin{array}{l}-0.03 \\
(0.03)\end{array}$ & $\begin{array}{c}0.02 \\
(0.04)\end{array}$ & $\begin{array}{l}-0.02 \\
(0.05)\end{array}$ \\
\hline Export & $\begin{array}{c}0.00 \\
(0.04)\end{array}$ & $\begin{array}{c}0.01 \\
(0.03)\end{array}$ & $\begin{array}{c}0.04 \\
(0.03)\end{array}$ & $\begin{array}{c}0.04 \\
(0.04)\end{array}$ & $\begin{array}{c}0.06 \\
(0.05)\end{array}$ \\
\hline Foreign owned & $\begin{array}{l}-0.02 \\
(0.07)\end{array}$ & $\begin{array}{l}-0.05 \\
(0.06)\end{array}$ & $\begin{array}{l}-0.02 \\
(0.05)\end{array}$ & $\begin{array}{c}0.04 \\
(0.06)\end{array}$ & $\begin{array}{l}-0.05 \\
(0.07)\end{array}$ \\
\hline Change in mobility & $\begin{array}{l}-0.03 \\
(0.02)\end{array}$ & $\begin{array}{l}-0.02 \\
(0.02)\end{array}$ & $\begin{array}{l}-0.03^{*} \\
(0.02)\end{array}$ & $\begin{array}{l}-0.01 \\
(0.02)\end{array}$ & $\begin{array}{l}-0.02 \\
(0.02)\end{array}$ \\
\hline Work experience & $\begin{array}{l}-0.00 \\
(0.00)\end{array}$ & $\begin{array}{l}-0.00 \\
(0.00)\end{array}$ & $\begin{array}{l}-0.00 \\
(0.00)\end{array}$ & $\begin{array}{c}-0.00 * * \\
(0.00)\end{array}$ & $\begin{array}{l}-0.00 \\
(0.00)\end{array}$ \\
\hline Post-graduate degree & $\begin{array}{c}0.16 * * * \\
(0.06)\end{array}$ & $\begin{array}{c}0.07 \\
(0.05)\end{array}$ & $\begin{array}{c}0.03 \\
(0.04)\end{array}$ & $\begin{array}{l}-0.01 \\
(0.04)\end{array}$ & $\begin{array}{c}0.15 * * * \\
(0.05)\end{array}$ \\
\hline Studying abroad & $\begin{array}{c}0.09 \\
(0.05)\end{array}$ & $\begin{array}{c}0.06 \\
(0.05)\end{array}$ & $\begin{array}{c}0.02 \\
(0.04)\end{array}$ & $\begin{array}{c}0.06 \\
(0.05)\end{array}$ & $\begin{array}{c}0.06 \\
(0.05)\end{array}$ \\
\hline Experience in large business & $\begin{array}{c}0.04 \\
(0.04)\end{array}$ & $\begin{array}{c}0.02 \\
(0.03)\end{array}$ & $\begin{array}{c}0.04 \\
(0.03)\end{array}$ & $\begin{array}{c}0.00 \\
(0.03)\end{array}$ & $\begin{array}{c}0.05 \\
(0.04)\end{array}$ \\
\hline Management Z-score & $\begin{array}{c}0.02 \\
(0.03)\end{array}$ & $\begin{array}{c}0.00 \\
(0.02)\end{array}$ & $\begin{array}{c}0.01 \\
(0.02)\end{array}$ & $\begin{array}{l}-0.01 \\
(0.02)\end{array}$ & $\begin{array}{c}0.00 \\
(0.03)\end{array}$ \\
\hline $\begin{array}{l}\text { Country-sector fixed effects } \\
\text { Observations } \\
\text { R-squared }\end{array}$ & $\begin{array}{l}\text { YES } \\
885 \\
0.16\end{array}$ & $\begin{array}{l}\text { YES } \\
891 \\
0.12\end{array}$ & $\begin{array}{l}\text { YES } \\
853 \\
0.19\end{array}$ & $\begin{array}{l}\text { YES } \\
605 \\
0.19\end{array}$ & $\begin{array}{l}\text { YES } \\
892 \\
0.12\end{array}$ \\
\hline
\end{tabular}

Table B1: Regressions of digitalization on technology sophistication. Note: $* * * p<0.01, * * p<$ $0.05, * p<0.1$ Robust standard errors in parentheses. The average marginal effects of independent variables are reported. 


\begin{tabular}{|c|c|c|c|c|c|}
\hline & $\begin{array}{c}(1) \\
\text { Increased } \\
\text { use of } \\
\text { digital } \\
\text { platforms }\end{array}$ & $\begin{array}{c}(2) \\
\text { New } \\
\text { investment } \\
\text { in digital } \\
\text { solutions }\end{array}$ & $\begin{array}{c}\text { (3) } \\
\text { More } \\
\text { work from } \\
\text { home }\end{array}$ & $\begin{array}{c}(4) \\
\text { More } \\
\text { online } \\
\text { sales }\end{array}$ & $\begin{array}{c}(5) \\
\text { Increased } \\
\text { use of } \\
\text { digital } \\
\text { tech }\end{array}$ \\
\hline 2 quantile & $\begin{array}{c}0.19 * * * \\
(0.05)\end{array}$ & $\begin{array}{c}0.12 * * * \\
(0.04)\end{array}$ & $\begin{array}{c}0.22 * * * \\
(0.04)\end{array}$ & $\begin{array}{c}0.14 * * * \\
(0.05)\end{array}$ & $\begin{array}{c}0.25 * * * \\
(0.05)\end{array}$ \\
\hline 3 quantile & $\begin{array}{c}0.32 * * * \\
(0.06)\end{array}$ & $\begin{array}{c}0.13 * * * \\
(0.05)\end{array}$ & $\begin{array}{c}0.22 * * * \\
(0.05)\end{array}$ & $\begin{array}{c}0.11 * * \\
(0.05)\end{array}$ & $\begin{array}{c}0.35 * * * \\
(0.06)\end{array}$ \\
\hline 4 quantile & $\begin{array}{c}0.29 * * * \\
(0.06)\end{array}$ & $\begin{array}{c}0.15^{* * *} \\
(0.05)\end{array}$ & $\begin{array}{c}0.24 * * * \\
(0.05)\end{array}$ & $\begin{array}{c}0.09 \\
(0.06)\end{array}$ & $\begin{array}{c}0.34 * * * \\
(0.07)\end{array}$ \\
\hline 5 quantile & $\begin{array}{c}0.31 * * * \\
(0.07)\end{array}$ & $\begin{array}{c}0.17 * * * \\
(0.05)\end{array}$ & $\begin{array}{c}0.26 * * * \\
(0.05)\end{array}$ & $\begin{array}{c}0.13 * * \\
(0.06)\end{array}$ & $\begin{array}{c}0.37 * * * \\
(0.07)\end{array}$ \\
\hline Medium & $\begin{array}{c}0.03 \\
(0.04)\end{array}$ & $\begin{array}{c}0.10 * * * \\
(0.03)\end{array}$ & $\begin{array}{l}0.04^{*} \\
(0.02)\end{array}$ & $\begin{array}{c}0.02 \\
(0.03)\end{array}$ & $\begin{array}{c}0.04 \\
(0.04)\end{array}$ \\
\hline Large & $\begin{array}{c}0.10 * * \\
(0.05)\end{array}$ & $\begin{array}{c}0.13 * * * \\
(0.04)\end{array}$ & $\begin{array}{c}0.06 * * \\
(0.03)\end{array}$ & $\begin{array}{c}0.03 \\
(0.04)\end{array}$ & $\begin{array}{l}0.09 * \\
(0.05)\end{array}$ \\
\hline Age 6 to 10 & $\begin{array}{l}-0.04 \\
(0.05)\end{array}$ & $\begin{array}{c}0.00 \\
(0.03)\end{array}$ & $\begin{array}{l}-0.00 \\
(0.03)\end{array}$ & $\begin{array}{c}-0.06^{*} \\
(0.03)\end{array}$ & $\begin{array}{c}0.05 \\
(0.05)\end{array}$ \\
\hline Age 11 to 15 & $\begin{array}{l}-0.03 \\
(0.05)\end{array}$ & $\begin{array}{l}-0.03 \\
(0.03)\end{array}$ & $\begin{array}{l}-0.03 \\
(0.03)\end{array}$ & $\begin{array}{l}-0.04 \\
(0.04)\end{array}$ & $\begin{array}{l}-0.00 \\
(0.05)\end{array}$ \\
\hline Age 16+ & $\begin{array}{l}-0.00 \\
(0.05)\end{array}$ & $\begin{array}{c}0.01 \\
(0.04)\end{array}$ & $\begin{array}{l}-0.02 \\
(0.03)\end{array}$ & $\begin{array}{c}0.02 \\
(0.05)\end{array}$ & $\begin{array}{l}-0.02 \\
(0.05)\end{array}$ \\
\hline Export & $\begin{array}{l}-0.00 \\
(0.04)\end{array}$ & $\begin{array}{c}0.01 \\
(0.03)\end{array}$ & $\begin{array}{c}0.04 \\
(0.03)\end{array}$ & $\begin{array}{c}0.04 \\
(0.04)\end{array}$ & $\begin{array}{c}0.06 \\
(0.05)\end{array}$ \\
\hline Foreign owned & $\begin{array}{l}-0.01 \\
(0.07)\end{array}$ & $\begin{array}{l}-0.04 \\
(0.06)\end{array}$ & $\begin{array}{l}-0.01 \\
(0.04)\end{array}$ & $\begin{array}{c}0.05 \\
(0.06)\end{array}$ & $\begin{array}{l}-0.04 \\
(0.07)\end{array}$ \\
\hline Change in mobility & $\begin{array}{l}-0.03 \\
(0.02)\end{array}$ & $\begin{array}{l}-0.02 \\
(0.02)\end{array}$ & $\begin{array}{l}-0.03 * \\
(0.02)\end{array}$ & $\begin{array}{l}-0.01 \\
(0.02)\end{array}$ & $\begin{array}{l}-0.02 \\
(0.02)\end{array}$ \\
\hline Work experience & $\begin{array}{l}-0.00 \\
(0.00)\end{array}$ & $\begin{array}{l}-0.00 \\
(0.00)\end{array}$ & $\begin{array}{l}-0.00 \\
(0.00)\end{array}$ & $\begin{array}{c}-0.00 * * * \\
(0.00)\end{array}$ & $\begin{array}{l}-0.00 \\
(0.00)\end{array}$ \\
\hline Post-graduate degree & $\begin{array}{c}0.16 * * * \\
(0.05)\end{array}$ & $\begin{array}{c}0.07 \\
(0.05)\end{array}$ & $\begin{array}{c}0.02 \\
(0.04)\end{array}$ & $\begin{array}{l}-0.01 \\
(0.04)\end{array}$ & $\begin{array}{c}0.14 * * * \\
(0.05)\end{array}$ \\
\hline Studying abroad & $\begin{array}{l}0.09 * \\
(0.05)\end{array}$ & $\begin{array}{c}0.06 \\
(0.05)\end{array}$ & $\begin{array}{c}0.02 \\
(0.04)\end{array}$ & $\begin{array}{c}0.05 \\
(0.05)\end{array}$ & $\begin{array}{c}0.07 \\
(0.05)\end{array}$ \\
\hline Experience in large business & $\begin{array}{c}0.05 \\
(0.04)\end{array}$ & $\begin{array}{c}0.03 \\
(0.03)\end{array}$ & $\begin{array}{c}0.04 \\
(0.03)\end{array}$ & $\begin{array}{c}0.01 \\
(0.03)\end{array}$ & $\begin{array}{c}0.06 \\
(0.04)\end{array}$ \\
\hline Management Z-score & $\begin{array}{c}0.02 \\
(0.03)\end{array}$ & $\begin{array}{c}0.01 \\
(0.02)\end{array}$ & $\begin{array}{c}0.02 \\
(0.02)\end{array}$ & $\begin{array}{l}-0.00 \\
(0.02)\end{array}$ & $\begin{array}{c}0.01 \\
(0.03)\end{array}$ \\
\hline Country-sector fixed effects & YES & YES & YES & YES & YES \\
\hline Observations & 885 & 891 & 853 & 605 & 892 \\
\hline R-squared & 0.18 & 0.12 & 0.23 & 0.20 & 0.14 \\
\hline
\end{tabular}

Table B2: Regressions of digitalization on quantiles of tech sophistication. $* * * p<0.01, * * p<$ $0.05, * p<0.1$ Robust standard errors in parentheses. The average marginal effects of independent variables are reported. 


\begin{tabular}{|c|c|c|c|c|c|}
\hline & $\begin{array}{c}(1) \\
\text { Average } \\
\text { change } \\
\text { in sales } \\
(\%)\end{array}$ & $\begin{array}{c}(2) \\
\text { Average } \\
\text { change } \\
\text { in sales } \\
(\%)\end{array}$ & $\begin{array}{c}(3) \\
\text { Average } \\
\text { change } \\
\text { in sales } \\
(\%)\end{array}$ & $\begin{array}{c}(4) \\
\text { Average } \\
\text { change } \\
\text { in sales } \\
(\%)\end{array}$ & $\begin{array}{c}(5) \\
\text { Average } \\
\text { change } \\
\text { in sales } \\
(\%)\end{array}$ \\
\hline Tech Sophistication & $\begin{array}{l}5.38^{*} \\
(2.75)\end{array}$ & $\begin{array}{l}5.82 * * \\
(2.75)\end{array}$ & $\begin{array}{l}6.23 * * \\
(2.72)\end{array}$ & $\begin{array}{l}7.77 * * \\
(3.14)\end{array}$ & $\begin{array}{l}5.38^{*} \\
(2.76)\end{array}$ \\
\hline Increased use of digital platforms & $\begin{array}{c}6.80^{* * * *} \\
(2.34)\end{array}$ & & & & \\
\hline New investment in digital solutions & & $\begin{array}{l}7.20 * * \\
(3.38)\end{array}$ & & & \\
\hline More work from home & & & $\begin{array}{c}11.93 * * * \\
(3.87)\end{array}$ & & \\
\hline More online sales & & & & $\begin{array}{c}16.34 * * * \\
(4.24)\end{array}$ & \\
\hline Increased use of digital tech & & & & & $\begin{array}{c}6.60 * * * \\
(2.24)\end{array}$ \\
\hline Medium & $\begin{array}{c}2.30 \\
(2.68)\end{array}$ & $\begin{array}{c}1.98 \\
(2.67)\end{array}$ & $\begin{array}{c}1.28 \\
(2.72)\end{array}$ & $\begin{array}{c}2.30 \\
(3.09)\end{array}$ & $\begin{array}{c}2.46 \\
(2.65)\end{array}$ \\
\hline Large & $\begin{array}{c}0.85 \\
(3.34)\end{array}$ & $\begin{array}{c}1.34 \\
(3.45)\end{array}$ & $\begin{array}{c}1.12 \\
(3.50)\end{array}$ & $\begin{array}{l}-1.06 \\
(4.00)\end{array}$ & $\begin{array}{c}1.69 \\
(3.37)\end{array}$ \\
\hline Age 6 to 10 & $\begin{array}{l}-3.97 \\
(3.30)\end{array}$ & $\begin{array}{l}-4.36 \\
(3.32)\end{array}$ & $\begin{array}{l}-2.77 \\
(3.38)\end{array}$ & $\begin{array}{l}-0.28 \\
(3.83)\end{array}$ & $\begin{array}{l}-4.66 \\
(3.30)\end{array}$ \\
\hline Age 11 to 15 & $\begin{array}{l}-1.84 \\
(3.67)\end{array}$ & $\begin{array}{l}-2.31 \\
(3.69)\end{array}$ & $\begin{array}{l}-0.25 \\
(3.77)\end{array}$ & $\begin{array}{c}1.15 \\
(4.19)\end{array}$ & $\begin{array}{l}-2.59 \\
(3.68)\end{array}$ \\
\hline Age $16+$ & $\begin{array}{l}-0.83 \\
(3.65)\end{array}$ & $\begin{array}{l}-1.43 \\
(3.67)\end{array}$ & $\begin{array}{c}0.42 \\
(3.77)\end{array}$ & $\begin{array}{c}2.39 \\
(4.27)\end{array}$ & $\begin{array}{l}-1.30 \\
(3.68)\end{array}$ \\
\hline Export & $\begin{array}{c}3.90 \\
(3.01)\end{array}$ & $\begin{array}{c}3.53 \\
(2.99)\end{array}$ & $\begin{array}{c}3.54 \\
(3.07)\end{array}$ & $\begin{array}{c}2.18 \\
(3.70)\end{array}$ & $\begin{array}{c}3.19 \\
(2.99)\end{array}$ \\
\hline Foreign owned & $\begin{array}{c}11.57 * * \\
(4.68)\end{array}$ & $\begin{array}{c}11.34 * * \\
(4.67)\end{array}$ & $\begin{array}{l}8.12 * \\
(4.76)\end{array}$ & $\begin{array}{c}6.81 \\
(5.70)\end{array}$ & $\begin{array}{c}11.27 * * \\
(4.69)\end{array}$ \\
\hline Change in mobility & $\begin{array}{c}4.91 * * * \\
(1.52)\end{array}$ & $\begin{array}{c}4.86 * * * \\
(1.55)\end{array}$ & $\begin{array}{c}5.05^{* * *} \\
(1.55)\end{array}$ & $\begin{array}{l}3.92 * * \\
(1.89)\end{array}$ & $\begin{array}{c}4.90 * * * \\
(1.50)\end{array}$ \\
\hline Work experience & $\begin{array}{l}-0.02 \\
(0.12)\end{array}$ & $\begin{array}{l}-0.01 \\
(0.12)\end{array}$ & $\begin{array}{l}-0.00 \\
(0.12)\end{array}$ & $\begin{array}{c}0.07 \\
(0.15)\end{array}$ & $\begin{array}{l}-0.01 \\
(0.12)\end{array}$ \\
\hline Post-graduate degree & $\begin{array}{c}1.99 \\
(3.74)\end{array}$ & $\begin{array}{c}2.50 \\
(3.73)\end{array}$ & $\begin{array}{c}2.98 \\
(3.88)\end{array}$ & $\begin{array}{c}4.85 \\
(4.45)\end{array}$ & $\begin{array}{c}2.01 \\
(3.70)\end{array}$ \\
\hline Studying abroad & $\begin{array}{c}-8.14 * * \\
(3.76)\end{array}$ & $\begin{array}{c}-8.27 * * \\
(3.76)\end{array}$ & $\begin{array}{l}-6.38^{*} \\
(3.85)\end{array}$ & $\begin{array}{l}-5.48 \\
(4.83)\end{array}$ & $\begin{array}{c}-8.27 * * \\
(3.77)\end{array}$ \\
\hline Experience in large business & $\begin{array}{c}2.69 \\
(2.81)\end{array}$ & $\begin{array}{c}2.40 \\
(2.81)\end{array}$ & $\begin{array}{c}2.12 \\
(2.88)\end{array}$ & $\begin{array}{c}2.44 \\
(3.31)\end{array}$ & $\begin{array}{c}2.24 \\
(2.81)\end{array}$ \\
\hline Management Z-score & $\begin{array}{c}0.28 \\
(1.88)\end{array}$ & $\begin{array}{c}0.45 \\
(1.88)\end{array}$ & $\begin{array}{c}0.24 \\
(1.93)\end{array}$ & $\begin{array}{l}-1.60 \\
(2.29)\end{array}$ & $\begin{array}{c}0.47 \\
(1.89)\end{array}$ \\
\hline Observations & 885 & 891 & 853 & 605 & 892 \\
\hline R-squared & 0.20 & 0.20 & 0.21 & 0.23 & 0.21 \\
\hline
\end{tabular}

Table B3: Regressions of sales on digitalization and tech sophistication. $* * * p<0.01, * * p<$ $0.05, * p<0.1$. Robust standard errors in parentheses. 


\begin{tabular}{|c|c|c|c|c|c|}
\hline & $\begin{array}{c}\text { Average } \\
\text { change } \\
\text { in sales } \\
(\%)\end{array}$ & $\begin{array}{c}\text { Average } \\
\text { change } \\
\text { in sales } \\
(\%)\end{array}$ & $\begin{array}{c}\text { Average } \\
\text { change } \\
\text { in sales } \\
(\%)\end{array}$ & $\begin{array}{c}\text { Average } \\
\text { change } \\
\text { in sales } \\
(\%)\end{array}$ & $\begin{array}{c}\text { Average } \\
\text { change } \\
\text { in sales } \\
(\%)\end{array}$ \\
\hline 2 quantile & $\begin{array}{c}3.77 \\
(3.79)\end{array}$ & $\begin{array}{c}4.15 \\
(3.79)\end{array}$ & $\begin{array}{c}2.44 \\
(3.87)\end{array}$ & $\begin{array}{c}4.26 \\
(4.79)\end{array}$ & $\begin{array}{c}3.42 \\
(3.81)\end{array}$ \\
\hline 3 quantile & $\begin{array}{c}10.16 * * \\
(4.30)\end{array}$ & $\begin{array}{c}11.13 * * * \\
(4.25)\end{array}$ & $\begin{array}{c}8.97 * * \\
(4.32)\end{array}$ & $\begin{array}{c}11.70 * * \\
(5.28)\end{array}$ & $\begin{array}{l}9.91 * * \\
(4.29)\end{array}$ \\
\hline 4 quantile & $\begin{array}{c}9.62 * * \\
(4.64)\end{array}$ & $\begin{array}{c}10.74 * * \\
(4.68)\end{array}$ & $\begin{array}{l}8.30 * \\
(4.73)\end{array}$ & $\begin{array}{c}12.17 * * \\
(5.61)\end{array}$ & $\begin{array}{c}9.75^{* * *} \\
(4.67)\end{array}$ \\
\hline 5 quantile & $\begin{array}{c}11.72 * * \\
(5.10)\end{array}$ & $\begin{array}{c}12.46 * * \\
(5.08)\end{array}$ & $\begin{array}{c}11.15^{* *} \\
(5.10)\end{array}$ & $\begin{array}{c}14.74 * * \\
(6.09)\end{array}$ & $\begin{array}{c}11.42^{* * *} \\
(5.12)\end{array}$ \\
\hline Increased use of digital platforms & $\begin{array}{c}6.27 * * * \\
(2.36)\end{array}$ & & & & \\
\hline New investment in digital solutions & & $\begin{array}{c}6.93 * * \\
(3.41)\end{array}$ & & & \\
\hline More work from home & & & $\begin{array}{c}11.49 * * * \\
(3.97)\end{array}$ & & \\
\hline More online sales & & & & $\begin{array}{c}16.20 * * * \\
(4.31)\end{array}$ & \\
\hline Increased use of digital tech & & & & & $\begin{array}{c}6.16^{* * * *} \\
(2.26)\end{array}$ \\
\hline Medium & $\begin{array}{l}2.08 \\
(2.69)\end{array}$ & $\begin{array}{c}1.73 \\
(2.68)\end{array}$ & $\begin{array}{l}1.16 \\
(2.74)\end{array}$ & $\begin{array}{c}2.01 \\
(3.13)\end{array}$ & $\begin{array}{c}2.22 \\
(2.66)\end{array}$ \\
\hline Large & $\begin{array}{c}0.62 \\
(3.36)\end{array}$ & $\begin{array}{l}1.11 \\
(3.48)\end{array}$ & $\begin{array}{c}1.02 \\
(3.53)\end{array}$ & $\begin{array}{l}-1.26 \\
(4.06)\end{array}$ & $\begin{array}{c}1.47 \\
(3.40)\end{array}$ \\
\hline Age 6 to 10 & $\begin{array}{l}-4.04 \\
(3.32)\end{array}$ & $\begin{array}{l}-4.40 \\
(3.34)\end{array}$ & $\begin{array}{l}-2.84 \\
(3.40)\end{array}$ & $\begin{array}{l}-0.30 \\
(3.89)\end{array}$ & $\begin{array}{l}-4.65 \\
(3.31)\end{array}$ \\
\hline Age 11 to 15 & $\begin{array}{l}-1.82 \\
(3.66)\end{array}$ & $\begin{array}{l}-2.30 \\
(3.69)\end{array}$ & $\begin{array}{l}-0.31 \\
(3.77)\end{array}$ & $\begin{array}{c}0.90 \\
(4.19)\end{array}$ & $\begin{array}{l}-2.57 \\
(3.67)\end{array}$ \\
\hline Age $16+$ & $\begin{array}{l}-0.78 \\
(3.69)\end{array}$ & $\begin{array}{l}-1.37 \\
(3.72)\end{array}$ & $\begin{array}{c}0.34 \\
(3.81)\end{array}$ & $\begin{array}{c}2.31 \\
(4.35)\end{array}$ & $\begin{array}{l}-1.26 \\
(3.72)\end{array}$ \\
\hline Export & $\begin{array}{c}3.64 \\
(3.01)\end{array}$ & $\begin{array}{c}3.28 \\
(2.99)\end{array}$ & $\begin{array}{c}3.43 \\
(3.07)\end{array}$ & $\begin{array}{c}1.91 \\
(3.70)\end{array}$ & $\begin{array}{c}2.99 \\
(2.99)\end{array}$ \\
\hline Foreign owned & $\begin{array}{c}11.41 * * \\
(4.65)\end{array}$ & $\begin{array}{c}11.14 * * \\
(4.64)\end{array}$ & $\begin{array}{l}8.13^{*} \\
(4.75)\end{array}$ & $\begin{array}{c}6.92 \\
(5.67)\end{array}$ & $\begin{array}{c}11.07 * * \\
(4.67)\end{array}$ \\
\hline Change in mobility & $\begin{array}{c}4.91 * * * \\
(1.49)\end{array}$ & $\begin{array}{c}4.89 * * * \\
(1.52)\end{array}$ & $\begin{array}{c}4.97 * * * \\
(1.53)\end{array}$ & $\begin{array}{l}3.82 * * \\
(1.83)\end{array}$ & $\begin{array}{c}4.91 * * * \\
(1.48)\end{array}$ \\
\hline Work experience & $\begin{array}{l}-0.01 \\
(0.12)\end{array}$ & $\begin{array}{l}-0.01 \\
(0.12)\end{array}$ & $\begin{array}{c}0.01 \\
(0.12)\end{array}$ & $\begin{array}{c}0.09 \\
(0.15)\end{array}$ & $\begin{array}{l}-0.01 \\
(0.12)\end{array}$ \\
\hline Post-graduate degree & $\begin{array}{c}2.07 \\
(3.71)\end{array}$ & $\begin{array}{c}2.55 \\
(3.69)\end{array}$ & $\begin{array}{c}3.25 \\
(3.85)\end{array}$ & $\begin{array}{c}5.35 \\
(4.41)\end{array}$ & $\begin{array}{c}2.14 \\
(3.67)\end{array}$ \\
\hline Studying abroad & $\begin{array}{c}-7.92 * * \\
(3.75)\end{array}$ & $\begin{array}{c}-8.10^{* *} \\
(3.73)\end{array}$ & $\begin{array}{l}-6.24 \\
(3.84)\end{array}$ & $\begin{array}{l}-5.49 \\
(4.81)\end{array}$ & $\begin{array}{c}-8.10^{* * *} \\
(3.76)\end{array}$ \\
\hline Experience in large business & $\begin{array}{c}2.93 \\
(2.80)\end{array}$ & $\begin{array}{c}2.64 \\
(2.78)\end{array}$ & $\begin{array}{c}2.44 \\
(2.87)\end{array}$ & $\begin{array}{l}2.90 \\
(3.28)\end{array}$ & $\begin{array}{c}2.47 \\
(2.79)\end{array}$ \\
\hline Management Z-score & $\begin{array}{c}0.34 \\
(1.86)\end{array}$ & $\begin{array}{c}0.53 \\
(1.87)\end{array}$ & $\begin{array}{c}0.34 \\
(1.92)\end{array}$ & $\begin{array}{l}-1.47 \\
(2.26)\end{array}$ & $\begin{array}{c}0.53 \\
(1.87)\end{array}$ \\
\hline Observations & 885 & 891 & 853 & 605 & 892 \\
\hline R-squared & 0.21 & 0.21 & 0.21 & 0.24 & 0.21 \\
\hline
\end{tabular}

Table B4: Regressions of sales on digitalization and quantiles of tech sophistication. $* * * p<$ $0.01, * * p<0.05, * p<0.1$ Robust standard errors in parentheses. 


\begin{tabular}{|c|c|c|c|c|c|}
\hline & $\begin{array}{c}(1) \\
\text { Average } \\
\text { change } \\
\text { in sales } \\
(\%)\end{array}$ & $\begin{array}{c}(2) \\
\text { Average } \\
\text { change } \\
\text { in sales } \\
(\%)\end{array}$ & $\begin{array}{c}(3) \\
\text { Average } \\
\text { change } \\
\text { in sales } \\
(\%)\end{array}$ & $\begin{array}{c}(4) \\
\text { Average } \\
\text { change } \\
\text { in sales } \\
(\%)\end{array}$ & $\begin{array}{c}(5) \\
\text { Average } \\
\text { change } \\
\text { in sales } \\
(\%)\end{array}$ \\
\hline Increased use of digital platforms & $\begin{array}{c}7.56 * * * \\
(3.03)\end{array}$ & & & & \\
\hline New investment in digital solutions & & $\begin{array}{c}17.63 * * * \\
(5.85)\end{array}$ & & & \\
\hline More work from home & & & $\begin{array}{c}4.05 \\
(8.84)\end{array}$ & & \\
\hline More online sales & & & & $\begin{array}{c}4.39 \\
(7.68)\end{array}$ & \\
\hline Increased use of digital tech & & & & & $\begin{array}{c}7.62 * * * \\
(2.82)\end{array}$ \\
\hline Country-sector fixed effects & YES & YES & YES & YES & YES \\
\hline Basic characteristics & YES & YES & YES & YES & YES \\
\hline Management & YES & YES & YES & YES & YES \\
\hline Observations & 837 & 882 & 643 & 603 & 889 \\
\hline
\end{tabular}

Table B5: Effects of digitalization on sales, propensity score matched sample. $* * * p<0.01, * * p<$ $0.05, * p<0.1$ Robust standard errors in parentheses. 


\begin{tabular}{|c|c|c|c|c|c|}
\hline & $\begin{array}{c}(1) \\
\text { Average } \\
\text { change } \\
\text { in sales } \\
(\%)\end{array}$ & $\begin{array}{c}(2) \\
\text { Average } \\
\text { change } \\
\text { in sales } \\
(\%)\end{array}$ & $\begin{array}{c}(3) \\
\text { Average } \\
\text { change } \\
\text { in sales } \\
(\%)\end{array}$ & $\begin{array}{c}(4) \\
\text { Average } \\
\text { change } \\
\text { in sales } \\
(\%)\end{array}$ & $\begin{array}{c}(5) \\
\text { Average } \\
\text { change } \\
\text { in sales } \\
(\%)\end{array}$ \\
\hline Increased use of digital platforms & $\begin{array}{c}8.68 * * * \\
(2.88)\end{array}$ & & & & \\
\hline New investment in digital solutions & & $\begin{array}{c}11.05^{* * *} \\
(5.00)\end{array}$ & & & \\
\hline More work from home & & & $\begin{array}{c}2.9 \\
(7.84)\end{array}$ & & \\
\hline More online sales & & & & $\begin{array}{l}18.28 \\
(6.67)\end{array}$ & \\
\hline Increased use of digital tech & & & & & $\begin{array}{c}8.77 * * * \\
(2.77)\end{array}$ \\
\hline Country-sector fixed effects & YES & YES & YES & YES & YES \\
\hline Basic characteristics & YES & YES & YES & YES & YES \\
\hline Management & YES & YES & YES & YES & YES \\
\hline Observations & 837 & 882 & 643 & 603 & 889 \\
\hline
\end{tabular}

Table B6: Effects of digitalization on sales, nearest neighbor matched sample. $* * * p<0.01, * * p<$ $0.05, * p<0.1$ Robust standard errors in parentheses. 


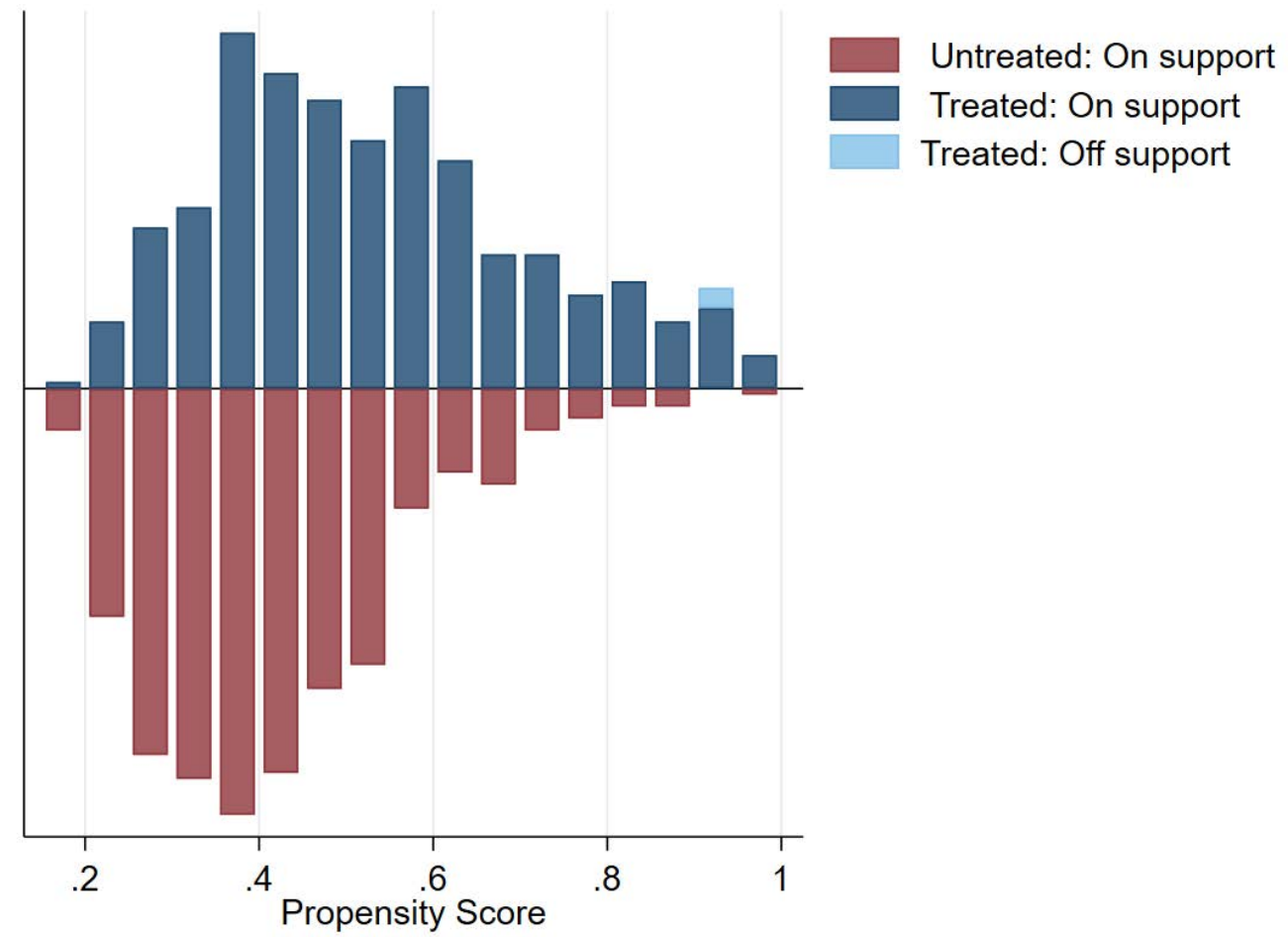

Figure B1: Common Support. Figure shows the extent to which distributions of propensity scores in treatment and comparison groups overlap. 


\begin{tabular}{|c|c|c|c|c|c|}
\hline Variable & $\begin{array}{c}(1) \\
\text { Treated }\end{array}$ & $\begin{array}{c}(2) \\
\text { Control }\end{array}$ & $\begin{array}{c}(3) \\
\text { Difference }\end{array}$ & $\begin{array}{c}(4) \\
\text { t statistic }\end{array}$ & $\begin{array}{c}(5) \\
\text { p-value }\end{array}$ \\
\hline Tech Sophistication & 1.95 & 1.64 & $0.31 * * *$ & 8.33 & 0.00 \\
\hline Medium & 0.27 & 0.25 & 0.01 & 0.51 & 0.61 \\
\hline Large & 0.29 & 0.15 & $0.14 * * *$ & 5.42 & 0.00 \\
\hline Age 6 to 10 & 0.25 & 0.20 & $0.05 * *$ & 1.97 & 0.05 \\
\hline Age 11 to 15 & 0.19 & 0.21 & -0.02 & -0.92 & 0.36 \\
\hline Age $16+$ & 0.38 & 0.37 & 0.00 & 0.14 & 0.89 \\
\hline Export & 0.26 & 0.17 & $0.08 * * *$ & 3.35 & 0.00 \\
\hline Foreign Owned & 0.14 & 0.10 & $0.04 *$ & 1.95 & 0.05 \\
\hline Change in mobility & -32.84 & -34.67 & 1.83 & 1.24 & 0.22 \\
\hline Work experience & 18.35 & 17.64 & 0.72 & 1.03 & 0.30 \\
\hline Post-graduate degree & 0.16 & 0.06 & $0.10 * * *$ & 5.27 & 0.00 \\
\hline Studying abroad & 0.24 & 0.14 & $0.10 * * *$ & 4.02 & 0.00 \\
\hline Experience in large business & 0.33 & 0.21 & $0.12 * * *$ & 4.47 & 0.00 \\
\hline Management Z-score & 0.21 & 0.05 & $0.17 * * *$ & 4.19 & 0.00 \\
\hline Senegal Agriculture & 0.05 & 0.12 & $-0.07 * * *$ & -3.95 & 0.00 \\
\hline Vietnam Agriculture & 0.06 & 0.07 & -0.01 & -0.69 & 0.49 \\
\hline Brazil Manufacturing less exposed & 0.02 & 0.00 & $0.01 * *$ & 2.11 & 0.04 \\
\hline Senegal Manufacturing less exposed & 0.04 & 0.04 & -0.01 & -0.75 & 0.45 \\
\hline Vietnam Manufacturing less exposed & 0.12 & 0.12 & 0.00 & -0.19 & 0.85 \\
\hline Brazil Manufacturing more exposed & 0.06 & 0.01 & $0.05 * * *$ & 4.02 & 0.00 \\
\hline Senegal Manufacturing more exposed & 0.08 & 0.10 & -0.02 & -0.98 & 0.33 \\
\hline Vietnam Manufacturing more exposed & 0.06 & 0.07 & -0.01 & -0.62 & 0.54 \\
\hline Brazil Services less exposed & 0.02 & 0.02 & 0.01 & 0.97 & 0.33 \\
\hline Senegal Services less exposed & 0.17 & 0.14 & 0.02 & 1.00 & 0.32 \\
\hline Vietnam Services less exposed & 0.19 & 0.16 & 0.03 & 1.23 & 0.22 \\
\hline Brazil Services more exposed & 0.00 & 0.01 & 0.00 & -0.31 & 0.76 \\
\hline Senegal Services more exposed & 0.06 & 0.08 & -0.02 & -1.06 & 0.29 \\
\hline Vietnam Services more exposed & 0.06 & 0.04 & 0.02 & 1.47 & 0.14 \\
\hline
\end{tabular}

Table B7: Unbalanced Covariate Differences between Treated and Control Group. $* * * p<$ $0.01, * * p<0.05, * p<0.1$ Robust standard errors in parentheses. Treatment group is the firms that increased use of digital technology. 


\begin{tabular}{|c|c|c|c|c|c|}
\hline Variable & $\begin{array}{c}(1) \\
\text { Treated }\end{array}$ & $\begin{array}{c}(2) \\
\text { Control }\end{array}$ & $\begin{array}{c}(3) \\
\text { Difference }\end{array}$ & $\begin{array}{c}(4) \\
\mathrm{t} \\
\text { statistic }\end{array}$ & $\begin{array}{c}(5) \\
\text { p-value }\end{array}$ \\
\hline Tech Sophistication & 1.90 & 1.89 & 0.01 & 0.29 & 0.77 \\
\hline Medium & 0.27 & 0.25 & 0.02 & 0.55 & 0.58 \\
\hline Large & 0.26 & 0.24 & 0.02 & 0.64 & 0.52 \\
\hline Age 6 to 10 & 0.25 & 0.28 & -0.03 & -0.94 & 0.35 \\
\hline Age 11 to 15 & 0.19 & 0.22 & -0.03 & -0.94 & 0.35 \\
\hline Age 16+ & 0.36 & 0.26 & $0.09 * * *$ & 2.93 & 0.00 \\
\hline Export & 0.26 & 0.20 & $0.06^{* *}$ & 2.07 & 0.04 \\
\hline Foreign Owned & 0.13 & 0.14 & -0.01 & -0.41 & 0.68 \\
\hline Change in mobility & -30.73 & -28.38 & -2.35 & -1.42 & 0.16 \\
\hline Work experience & 17.83 & 16.49 & $1.34^{*}$ & 1.85 & 0.07 \\
\hline Post-graduate degree & 0.16 & 0.15 & 0.01 & 0.58 & 0.57 \\
\hline Studying abroad & 0.22 & 0.21 & 0.01 & 0.34 & 0.74 \\
\hline Experience in large business & 0.31 & 0.30 & 0.01 & 0.45 & 0.65 \\
\hline Management Z-score & 0.20 & 0.15 & 0.05 & 1.03 & 0.30 \\
\hline Senegal Agriculture & 0.06 & 0.04 & 0.01 & 0.80 & 0.42 \\
\hline Vietnam Agriculture & 0.06 & 0.07 & -0.01 & -0.42 & 0.68 \\
\hline Brazil Manufacturing less exposed & 0.02 & 0.03 & -0.01 & -0.70 & 0.49 \\
\hline Senegal Manufacturing less exposed & 0.04 & 0.02 & 0.01 & 1.01 & 0.31 \\
\hline Vietnam Manufacturing less exposed & 0.11 & 0.11 & 0.01 & 0.44 & 0.66 \\
\hline Brazil Manufacturing more exposed & 0.06 & 0.07 & -0.01 & -0.55 & 0.58 \\
\hline Senegal Manufacturing more exposed & 0.08 & 0.06 & 0.01 & 0.80 & 0.42 \\
\hline Vietnam Manufacturing more exposed & 0.06 & 0.06 & 0.00 & 0.00 & 1.00 \\
\hline Brazil Services less exposed & 0.03 & 0.01 & 0.02 & 2.16 & 0.03 \\
\hline Senegal Services less exposed & 0.15 & 0.15 & 0.00 & 0.19 & 0.85 \\
\hline Vietnam Services less exposed & 0.21 & 0.24 & -0.03 & -1.16 & 0.25 \\
\hline Brazil Services more exposed & 0.00 & 0.01 & 0.00 & -0.82 & 0.41 \\
\hline Senegal Services more exposed & 0.05 & 0.05 & 0.00 & 0.00 & 1.00 \\
\hline Vietnam Services more exposed & 0.06 & 0.08 & -0.02 & -0.93 & 0.35 \\
\hline
\end{tabular}

Table B8: PSM Balanced Covariate Differences between Treated and Control Group. $* * * p<$ $0.01, * * p<0.05, * p<0.1$ Robust standard errors in parentheses. Treatment group is the firms that increased use of digital technology. 